\title{
Cultural Resources Survey for the Proposed MUD 121 Brazos River Levee Protection Project in Fort Bend County, Texas
}

Michael Quennoz

Tony Scott

Follow this and additional works at: https://scholarworks.sfasu.edu/ita

Part of the American Material Culture Commons, Archaeological Anthropology Commons, Environmental Studies Commons, Other American Studies Commons, Other Arts and Humanities Commons, Other History of Art, Architecture, and Archaeology Commons, and the United States History Commons

Tell us how this article helped you.

This Article is brought to you for free and open access by the Center for Regional Heritage Research at SFA ScholarWorks. It has been accepted for inclusion in Index of Texas Archaeology: Open Access Gray Literature from the Lone Star State by an authorized editor of SFA ScholarWorks. For more information, please contact cdsscholarworks@sfasu.edu. 


\section{Cultural Resources Survey for the Proposed MUD 121 Brazos River Levee Protection Project in Fort Bend County, Texas}

\section{Creative Commons License}

\section{(c) (1) \&}

This work is licensed under a Creative Commons Attribution-NonCommercial 4.0 International License 
GRAY \& PAPE

HERITAGE MANAGEMENT
Cultural Resources Survey for the Proposed MUD 121 Brazos River Levee Protection Project

in Fort Bend County, Texas

Lead Agency:

Texas Historical Commission

Permit \#8734

\section{PREPARED FOR:}

Berg-Oliver Associates, Inc. 14701 St. Mary's Lane, Suite 400 Houston, Texas 77079

\section{PREPARED BY: \\ Gray \& Pape, Inc.}

110 Avondale Street

Houston, Texas 77006 


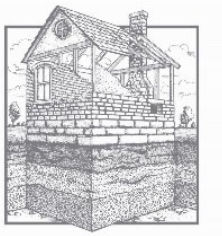

\section{GRAY \& PAPE \\ HERITAGE MANAGEMENT}

Project No. 19-70701.001

Cultural Resources Survey for the Proposed MUD 121 Brazos River Levee Protection Project in Fort Bend County, Texas

Texas Antiquities Permit No. 8734

Prepared for:

Berg-Oliver Associates, Inc.

14701 St. Mary's Lane, Suite 400

Houston, Texas 77079

Contact: Dean Edwards

(281) 854-6192

Prepared by:

Michael Quennoz

Tony Scott

Gray \& Pape, Inc.

110 Avondale Street

Houston, Texas 77006

(713) 541-0473

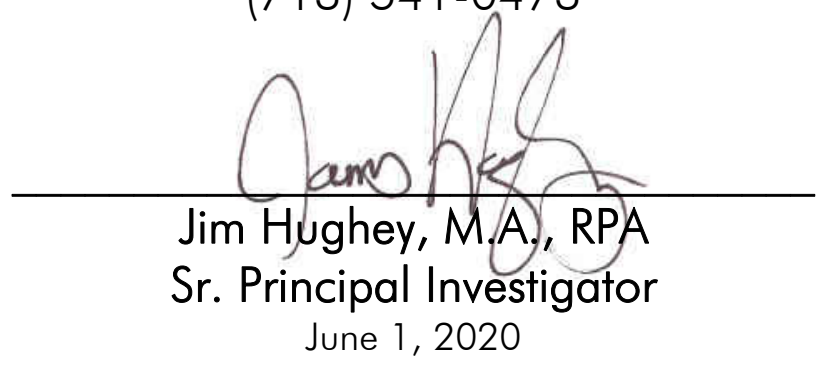




\section{ABSTRACT}

This report summarizes the results of a cultural resources survey by Gray \& Pape, Inc. of an approximately 14.8-hectare (36.6-acre) property in Fort Bend County, Texas, planned for a bank stabilization project on behalf of their client, Berg-Oliver Associates, Inc. The goals of the survey were to determine if the proposed project would affect any previously identified archaeological sites as defined by Section 106 of the National Historic Preservation Act of 1966, as amended (36 CFR 800), and to establish whether or not previously unidentified buried archaeological resources were located within the project's Area of Potential Effect. Portions of the project are on property owned by Fort Bend County Municipal Utility District Number 121, political subdivisions of the state, as such, a Texas Antiquities Permit (Permit Number 8734) was required prior to the commencement of fieldwork. All fieldwork and reporting activities were completed with reference to state (the Antiquities Code of Texas) and federal guidelines.

Prior to fieldwork mobilization, a background literature and site file search were conducted to identify the presence of recorded sites and previous cultural resource surveys within or near the project area. The search indicated that no previously identified archaeological sites, cemeteries, historic markers, or National Register properties are located within the project area. The same research identified that eight previous cultural resource surveys had been conducted within the study radius of the project area, one of which overlapped with the current project area. In addition, 14 previously recorded archaeological sites are located within the study radius, none of which are located within or immediately adjacent to the current project area.

Field investigations were carried out in two mobilizations in January and December 2019 and consisted of a combination of pedestrian survey and subsurface testing, resulting in the excavation of 32 shovel tests. Five planned tests were left unexcavated due to inundation, and eight planned tests were left unexcavated due to significant surface disturbance. All shovel tests were negative for cultural resource material and no historic-age resources were identified during survey. After a revised scope of work was submitted to the Texas Historical Commission, investigation of deeply buried soils took place tandem with construction by regular monitoring of construction excavation. When the construction schedule allowed, traditional deep testing, by means of mechanical excavation, was carried out in five of six areas anticipated to have deep impacts from the proposed bank stabilization project. A total of 22 trenches were excavated. No buried features or deeply buried paleosols were encountered.

Gray \& Pape, Inc. archaeologists are of the opinion that the shovel test survey and deep testing completed within the Area of Potential Effects has adequately assessed the potential for surface and near surface intact, significant cultural resources, as well as determining the potential for deeply buried resources or paleosols. No artifacts or cultural features were encountered during the course of the survey, and no new archaeological sites were identified. No negative impacts on any previously identified sites are anticipated from the proposed project. Based on these results, Gray \& Pape, Inc. recommends that no further cultural work be required and that the project be cleared to proceed as planned. As required under the provisions of Texas Antiquities Code Permit 8734, all project records are housed at the Center for Archaeological Studies at Texas State University, San Marcos, Texas. 


\section{TABLE OF CONTENTS}

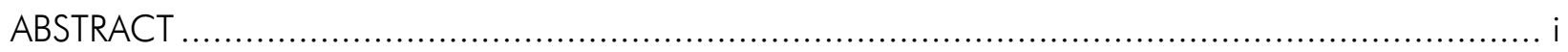

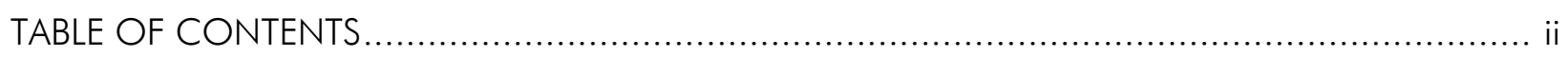

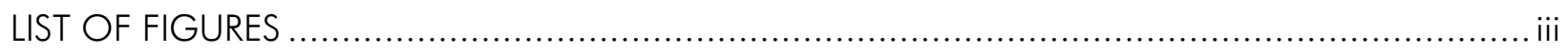

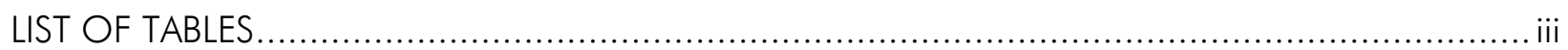

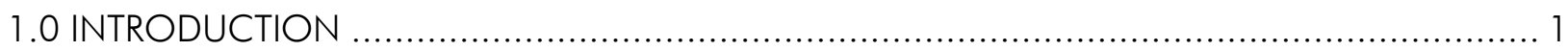

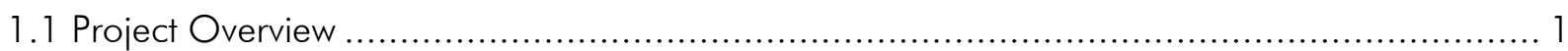

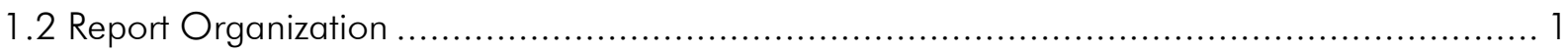

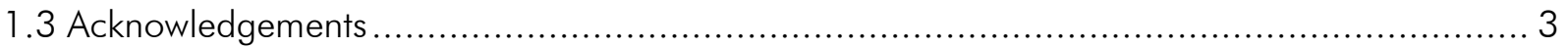

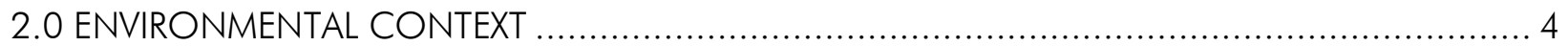

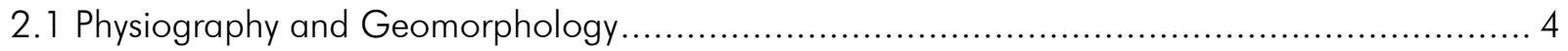

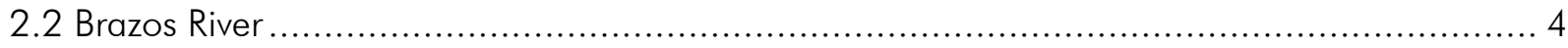

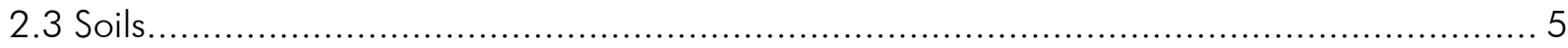

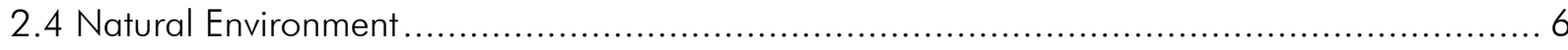

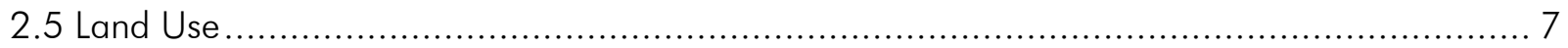

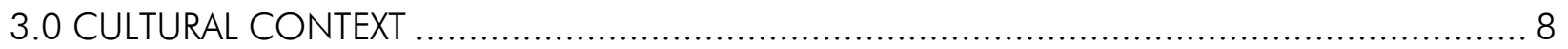

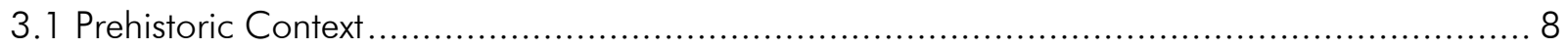

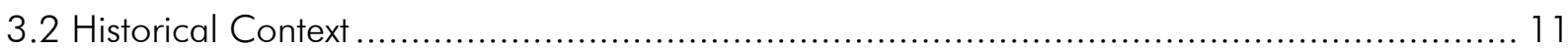

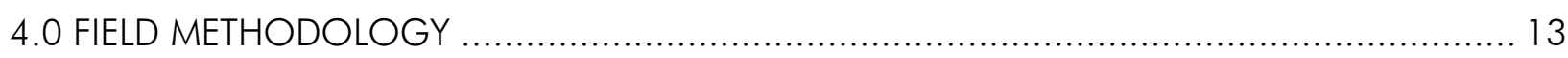

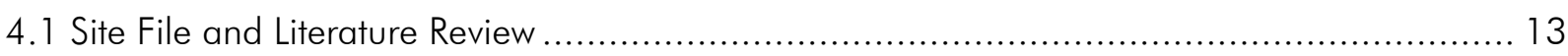

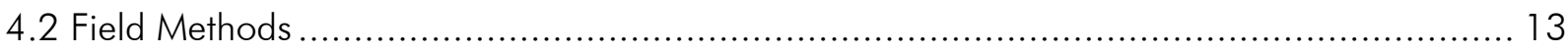

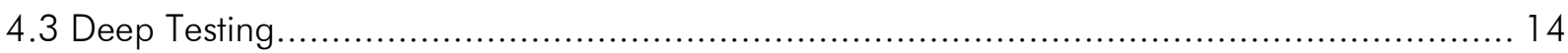

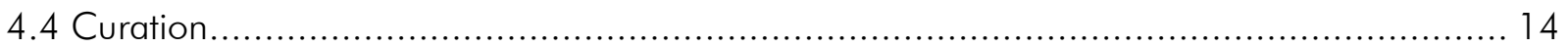

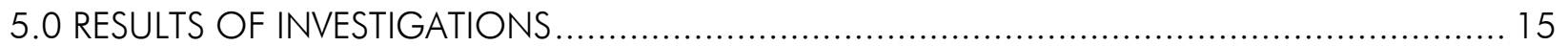

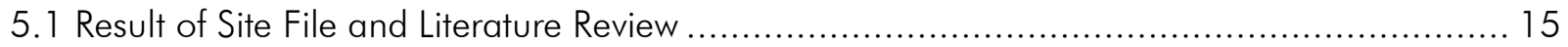

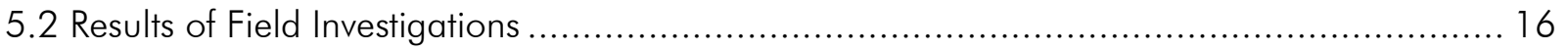

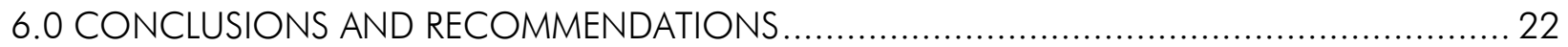

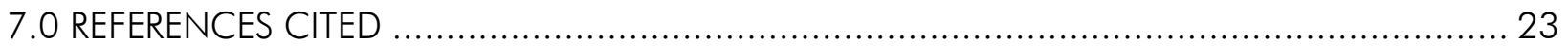


APPENDIX A: Trench Tables

APPENDIX B: Trench Profile Photographs

\section{LIST OF FIGURES}

Figure 1-1. Project area location in Fort Bend County, Texas. ............................................... 2

Figure 5-1. Project area with field survey results...................................................... 17

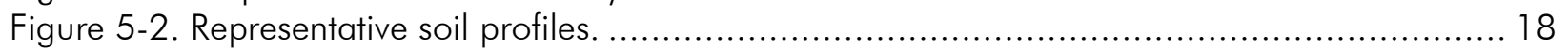

Figure 5-3. Inundated portion of the APE. View is to the northeast. .................................. 19

Figure 5-4. Levee road with inundated ditches at the western end of the APE. View is to the northwest.

Figure 5-5. Flooded ditches and spoil piles in the eastern portion of the APE. View is to the southwest.

Figure 5-6. Workspace 3 with pre-existing culvert and drainage. View is to the east.................... 20 Figure 5-7. Deep test and monitoring areas conducted within the APE, overlaid on aerial imagery circa 2017. 21

\section{LIST OF TABLES}

Table 5-1. Previously Recorded Area and Linear Surveys within 1.6 kilometers of the Proposed Project Area, Fort Bend County, Texas. ....................................................................... 15 Table 5-2. Previously Recorded Archaeological Sites within 1.6 kilometers of the Proposed Project Area, Fort Bend County, Texas. 16 


\subsection{INTRODUCTION}

Berg-Oliver Associates, Inc. (Berg-Oliver), of Houston, Texas, contracted with Gray \& Pape, Inc. (Gray \& Pape), of Houston, Texas, to perform an intensive pedestrian cultural resources survey combined with deep testing and select monitoring of a 14.8-hectare (36.6acre) area for a planned bank stabilization project in Fort Bend County, Texas.

The goals of the survey were to determine if the proposed project would affect any previously identified archaeological sites as defined by Section 106 of the National Historic Preservation Act (NHPA) of 1966, as amended (36 CFR 800), and to establish whether or not previously unidentified buried archaeological resources were located within the project's Area of Potential Effects (APE). Portions of the APE are on property owned by Fort Bend County Municipal Utility District Number 121 (MUD 121), political subdivisions of the state, as such, a Texas Antiquities Permit (Permit Number 8734) was required prior to the commencement of fieldwork. All fieldwork and reporting activities were completed with reference to state (the Antiquities Code of Texas) and federal (NHPA) guidelines.

\subsection{Project Overview}

The APE is located on the Sugarland, TX United States Geological Survey (USGS) 7.5-minute topographic quadrangle map (USGS 1980) and covers an area of approximately 14.8 hectares (36.6-acres) in Fort Bend County, Texas, 3 kilometers (1.9 miles) east of the City of Richmond (Figure 1-1). The APE runs parallel to the south bank of the Brazos River for approximately 1.2 kilometers (0.8 miles) while the southern edge of the APE is defined by existing levees and canals providing flood protection to the Riverpark West subdivision. The APE varies from between 80 and 270 meters ( 260 to 890 feet) in width. At the eastern end of the APE is property utilized by Gulf Coast
Stabilized Materials, a sand and gravel supplier, and the western most portion of the APE lies within the Long Acres Ranch, a private outdoor education facility.

Current project plans call for the installation of six gravity structures constructed to act as 'bendway weirs' that will mitigate erosion along the south bank of the Brazos River in the project area. This will involve the clearing and grubbing of approximately 8 hectares (20 acres) within the APE and the construction of a 1,737-meter $(5,700$-foot) long access road. Depths of impact from this portion of the project should be limited to the near surface. The excavation of a 37 by 12 -meter (120 by 40 -foot) trench will serve as the footprint of each of the six structures. Each trench will be between 3.0 and 3.7 meters (10 and 12 feet) deep. Within each project footprint, an auger will be used to excavate a shaft to a depth of 18 meters $(60$ feet) that will then be filled with concrete. After the concrete has strengthened, the trench will be back filled, and the excavation returned to the approximate pre-project grade.

\subsection{Report Organization}

This report is organized into seven numbered chapters and two lettered appendices. Chapter 1.0 provides an overview of the project. Chapter 2.0 presents an overview of the environmental setting and geomorphology. Chapter 3.0 presents a discussion of the cultural context associated with the APE. Chapter 4.0 presents the research design and methods developed for this investigation. The results of this investigation are presented in Chapter 5.0. Chapter 6.0 presents the investigation summary and provides recommendations based on the results of field survey. A list of literary references cited in the body of the report is provided in Chapter 7.0. Appendix A includes a table of excavated trenches and Appendix $B$ provides photos of the trench excavations. 


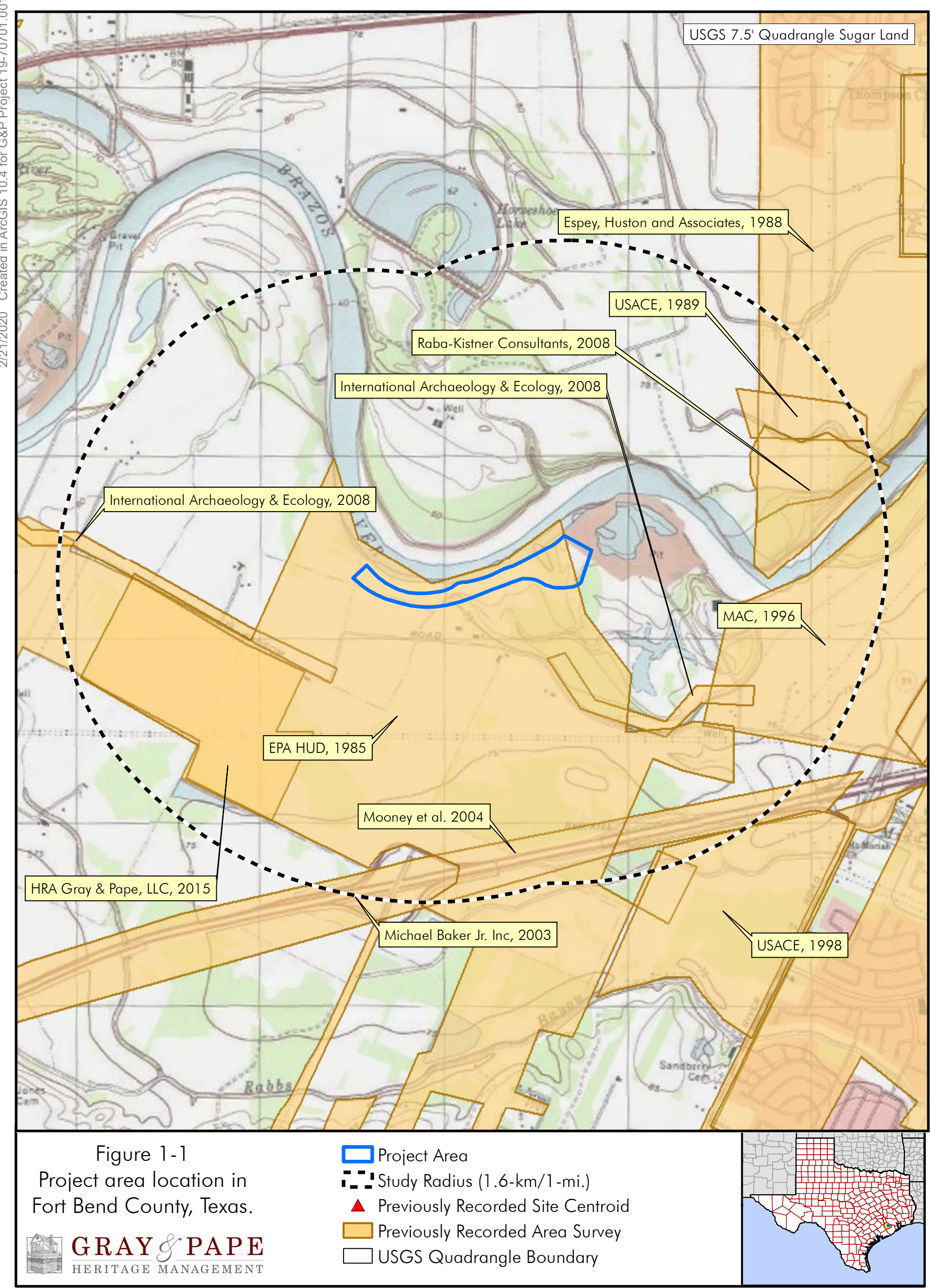




\subsection{Acknowledgements}

The intensive pedestrian survey was completed by Archaeologists Michael Quennoz and Jacob Hilton, under the supervision of Sr. Principal Investigator James Hughey, on January 31 and February 1, 2019. Principal Investigator Tony Scott, Mr. Quennoz, and Archaeologist Jessica Bludau conducted a combination of deep testing and excavation monitoring between December 12 and 16, 2019. The backhoe equipment and qualified operators were provided by Raito, Inc. The fieldwork required 84-person hours to complete. Mr. Quennoz prepared the report. Mr. Scott produced graphics. Jessica Bludau edited and produced the report. 


\subsection{ENVIRONMENTAL CONTEXT}

\subsection{Physiography and Geomorphology}

The Texas Coastal Plain makes up part of the larger Gulf Coastal Plain, a low level to gently sloping region extending from Florida to Mexico. The Texas Coastal Plain reaches as far north as the Ouachita uplift in Oklahoma, and as far west as the Balcones escarpment in central Texas. The basic geomorphological characteristics of the Texas coast and associated inland areas, which includes Fort Bend County, resulted from depositional conditions influenced by the combined action of sea level changes from glacial advance in the northern portions of the continent, and subsequent downcutting and variations in the sediment load capacity of the region's rivers. Locally, Fort Bend County is underlain by relatively recent sedimentary rocks and unconsolidated sediments ranging in age from the Miocene to Holocene (Abbott 2001; Van Siclen 1991).

Although older geologic units have been identified in the region (Abbott 2001; Barnes 1982; Van Siclen 1991), units relevant to the study of long-term human occupation in modern-day Fort Bend County include the Beaumont Formation, generally believed to predate human occupation in the region, the so-called "Deweyville Terraces", stratigraphically positioned between the Beaumont and Recent deposits. Holocene alluvium underlies the project area (Barnes 1982). These deposits are made up of clay, silt, and sand. This includes stream channel, point bar, natural levee, back swamp, and mud flat deposits (Barnes 1982). Gilgae, a succession of microbasins and microknolls in generally level areas or microvalleys and microridges parallel to the slope are common microfeatures.

The date of deposition for the Deweyville Terraces is not known. However, Abbott
(2001:16) among others believes the northsouth oriented terraces aggraded during the Late Pleistocene from overbank deposition of rivers and streams including the ancient Brazos River prior to the beginning of the Holocene. Abbott suggests that aggradation ended by approximately 20,000 years before present (B.P.) (Abbott 2001:106). However, meanders of rivers including the Brazos cut valleys through these terraces regularly during the Holocene and then abandoned them. This process leaves large, flat, open, and well drained areas favored for campsites. While all depositional facies other than channels have the potential to preserve archaeological sites, behaviorally, human activity favors well drained, sandy channel-proximal localities over flood basin muds (Abbott 2001:126). Other Recent or Holocene deposits on the Gulf Plain typically result from overbank flooding of extant streams, eolian transport including dune formation, and infilling of marshes.

\subsection{Brazos River}

At 1,350 kilometers (840 miles) in length, the Brazos River is the largest fluvial system located primarily within the state of Texas. The modern lower Brazos, including the project area where the river flows through Richmond, is categorized as a meandering type stream. Meandering streams are typified by a single, sinuous channel. These streams migrate laterally, eroding exterior banks and redepositing sediment on interior banks, creating point bars. Deposition also occurs during flood events, natural levee deposits along the margins of the stream and flood basin deposits across the floodplain. In addition to lateral migration, meandering streams can move across the landscape by meander cutoff and avulsion. A meander cutoff occurs when a bend in the stream forms to such an extreme the steam is able to cut across the neck and form a new channel. The abandoned bend becomes an oxbow lake which then begins to fill with 
sediment. In an avulsion, a new dominant channel forms during a flood event, the abandoned channel might infill or become occupied by a smaller stream. Within alluvial depositional settings the highest potential for archaeological site preservation can be found in point bar, levee, and proximal flood basin deposits (Abbott 2001). Paleosols, which form during periods of depositional stability, are also archaeologically important because of their ability to inform on previous environmental conditions, topography, and stratigraphic markers (Waters 1992).

Based on the chronology developed by Waters and Nordt (1995), between 18,000 to 8,500 years B.P., the cooler and wetter Pleistocene climate resulted in a larger, higher discharge stream that migrated laterally across the entire Brazos floodplain valley. While the current Brazos possesses a bankfull width of 100 to 500 meters (330 to 1,640 feet), the Pleistocene Brazos has an estimated bankfull width of 800 meters (2,600 feet) (Abbott 2001:107). With a shift to a warmer, drier climate in the Holocene, stream discharge decreased, channels of the Brazos became smaller and confined to a much narrower meander belt. Deposition becomes more a factor of vertical accretion than lateral migration. This resulted in a series of avulsion events throughout the Holocene that created sequential meander belts. The earliest of these avulsions occurred sometime between 8,400 and 8,100 years B.P. Between 4,200 and 2,500 B.P., a period of stability resulted in the formation of the Buffalo paleosol. Around 2,500 years B.P., a second avulsion occurred and, in many places, completely eroded away the Buffalo paleosol. From 1,250 years B.P. to 500 years B.P., deposition again slowed and the Asa paleosol formed. This was followed by a third avulsion event and the formation of the Katie paleosol. The modern Brazos River channel is the result of a fourth avulsion around 300 years B.P. (Waters and Nordt 1995). Based on site location data, Aten suggested that the Brazos River abandoned the Oyster Creek meander channel for its modern meander belt by around 1,500 B.P. (Aten 1983).
Examination of current and historical aerial images of the Brazos River near Richmond, Texas, provide examples of cutoff abandonment of meander bends, forming oxbow lakes, including Old River Lake and Horseshoe Lake. Also visible in the aerial images, is continued lateral migration of the river channel, with the erosion of cut banks on exterior bends and growing point bars on the interior bends (Google Inc. 2019, Nationwide Environmental Title Research LLC [NETR] 2019). Analysis of maps between 1941 and 2012 suggests that near Richmond, the river has shifted in excess of 120 meters (400 feet), with individual storm events resulting in up to 3 meters (10 feet) of bank erosion (United States Army Corps of Engineers [USACE] 2014). An anecdotal account claims that the original Lamar home, built east of Richmond, on the south bank of the Brazos River, collapsed into the river due to bank erosion (Gilmer 2015). In tandem with the erosion of the cut banks in the vicinity of Richmond, there appears to be a corresponding accretion of point bar deposits. A study of onepoint bar deposit demonstrated that a point bar 457 meters (1,500 feet) wide and 15 meters (50 feet) wide formed in only the last few hundred years. Any cultural material recovered from such a depositional environment would be likely to have very high stratigraphic resolution (Abbott 2001:111).

\subsection{Soils}

Four soil series are mapped within the APE: Brazoria clay, Clemville silt loam, Clemville silty clay loam, Sandy alluvial land, and Borrow Pits (Soil Survey Staff, Natural Resources Conservation Service, United States Department of Agriculture [SSS NRCS USDA] 2019). The Brazoria and Clemville soils occur in the western third of the APE, while the Sandy alluvium occupies most the eastern portion. At the far eastern area of the APE are the former borrow pits.

The Brazoria series consists of very deep, moderately well drained, very slowly permeable soils formed in clayey alluvial sediments on the 
flood plains of the Brazos and Colorado Rivers. A typical soil profile consists of 42 centimeters (17 inches) of dark brown (7.5YR 3/2) clay underlain by a brown (7.5YR 4/2) clay from 42 to 70 centimeters ( 17 to 28 inches) below the surface. From 70 to 90 centimeters (28 to 36 inches), is a mix of 90 percent reddish brown (5YR 4/4) and 10 percent dark reddish brown (5YR 3/2) clays. At 90 centimeters (36 inches) and continuing to 125 centimeters (49 inches), is a very dark brown (1OYR $2 / 2$ clay), which is underlain by a mix of 90 percent very dark brown (7.5YR 2.5/2) and 10 percent black (7.5YR 2.5/1) clays to a depth of 146 centimeters (58 inches) below the surface. Between 146 to 170 centimeters (58 to 67 inches), is a mix of 90 percent dark brown (7.5YR 3/3) and 10 percent dark brown (7.5YR3/2) clay. A mix of 30 percent dark reddish brown (5YR 3/2) and 70 percent dark reddish brown (5YR 3/3) clay can be found between 170 to 203 centimeters $(67$ to 80 inches) below the surface (SSS NRCS USDA 2019). Brazoria soils have moderate-high geoarchaeological potential (Abbott 2001).

Clemville series soils consist of very deep, well drained soils formed in loamy and clayey calcareous alluvial sediments, commonly found along flood plains. A typical soil profile consists of 31 centimeters (12 inches) of a brown (7.5YR4/4) silty clay loam underlain by a light brown (7.5YR4/4) silt loam with thin lenses of reddish brown (5YR5/4) or brown (7.5YR5/4) silty clay loam to a depth of 76 centimeters (30 inches) below the surface. From 76 to 127 centimeters ( 30 to 50 inches), is a buried A soil horizon that is a dark brown (7.5YR3/3) silty clay. This finally gives way to a reddish brown (5YR4/3) silty clay that extends to 203 centimeters (80 inches) below the surface (SSS NRCS USDA 2019). Abbott (2001) considers Clemville soils to have a very high geoarchaeological potential.

Sandy alluvial land consists of stratified deposits of alluvium in bends of the Brazos River, ranging from loamy sands to clays. These are typically in lower lying areas from the normal waterline to
7 meters (25 feet) above it (Mowery et al 1960). The Borrow Pit area at the eastern end of the APE is associated with the excavation of sandy soils for the construction materials industry.

\subsection{Natural Environment}

\subsubsection{Flora and Fauna}

Fort Bend County lies at the southwestern boundary of the Austroriparian biotic province as defined by Blair (1950). The project area is located within the Floodplains and Low Terraces sub region of the Western Gulf Coastal Plain Ecoregion (Griffith et al. 2007). Evidence from pollen analysis in Central Texas suggests that, at least during the Late Pleistocene, the area may have been populated by vegetative species that were tolerant of a cold weather environment. Climactic flux during the Holocene would eventually result in a gradual trend towards warmer weather, similar to that seen today (Abbott 2001).

Late Pleistocene flora may have included populations of spruce, poplar, maple, and pine (Holloway 1997), in an oak woodland environment that would eventually transition to an oak savanna in the late Holocene (Abbott 2001). Fauna during this time would include currently present species such as white-tailed deer and various smaller game, as well as bison, and, in localized areas, pronghorn sheep, and the American alligator (Abbott 2001).

The modern vegetative community associated with this region consists of a diverse collection of primarily deciduous trees and undergrowth (Abbott 2001). Modern land alteration activities, especially those associated with agriculture, have resulted in the removal of native plant species from the area. Commonly identified trees include water oak, pecan, various elms, cedar, oaks, sweetgum, Chinese tallow, and mulberry. Honeysuckle, dewberry, ragweed, yaupon, and blackberry are common, as are indiangrass and bluegrasses and various types of briars and vines (Abbott 2001). 
The modern faunal community includes mammals such as deer, squirrel, opossum, raccoon, skunk and various small rodents, numerous bird species, and reptiles including the Texas rat snake, the western cottonmouth, the kingsnake, and turtle species. Black bear and bison were present occasionally in the past (Abbott 2001). A sounder of feral hogs were encountered during survey and numerous wallows were observed.

\subsubsection{Climate}

Fort Bend County's close proximity to the Gulf of Mexico tends to influence the temperature, rainfall, and relative humidity of the region. Winds usually trend from the southeast or east, except during winter months when highpressure systems can bring in polar air from the north. Average temperatures in the summer can reach well above 30 degrees Celsius $(90$ degrees Fahrenheit), and are often accompanied by equally high humidity. Although winter temperatures can reach below 0 degrees Celsius (30 degrees Fahrenheit), below freezing temperatures usually occur on only a few days out of every year and are typically restricted to the early morning hours (Mowery et al. 1960).

Rainfall is even throughout the year, with an average monthly distribution ranging from between 43 centimeters (17 inches) to trace amounts; rainfall comes primarily from thunderstorms, which tend to be heavy but of short duration (Mowery et al. 1960).

\subsection{Land Use}

The earliest detailed map of the project area consulted was a 1929 USACE map produced from data gathered between 1910 and 1915 . The map shows no structures or roads in the current project area (USACE 1929). A 1953 aerial image and 1957 topographic map largely matches what is depicted on the earlier map. There are no structures visible and the area is mostly open pasture, dotted by sparse tree cover in its western half. An unnamed drainage runs north to south through the APE as does a gravel road connecting Ransom Road to a gravel bar on the Brazos River. The 1957 topographic map for the area shows a windmill in the vicinity of the APE's easternmost portion. A 1968 aerial image is the first to show a structure, most likely a barn or outbuilding, built near the southwestern edge of the APE (NETR 2019).

The first significant impacts within the project APE appear in 1995 with a gravel and sand pit operation at the eastern extent of the project area. Beginning in the early 2000s, residential development becomes increasingly apparent south of the APE. This included significant canal and levee construction along the southern portion of the APE. The APE has become increasingly wooded since the construction of the flood control system (Google, Inc. 2019). Aerial imagery between 1995 and 2009 show numerous impacts, particularly on the western half of the APE. These appear to be mostly roads, ditches, and berms.

Also apparent from the historical aerial imagery is the shifting course of the Brazos River. Along most of the APE, the river appears to be shifting southward. In places the current bank is as much as 213 meters (700 feet) south of where it was in 1953 (Google, Inc. 2019; NETR 2019). 


\subsection{CULTURAL CONTEXT}

\subsection{Prehistoric Context}

Traditionally, Southeast Texas has been viewed as a buffer zone between cultural regions in prehistoric times. Patterson (1995) describes the archaeological record in this area as being an interface between the Southern Plains and the Southeast Woodlands. Along similar lines, both Shafer (1975) and Aten (1984) have categorized the Post-Archaic archaeological record of this region as Woodland. This categorization is not meant to literally invoke the exact cultural patterns and chronology of the Woodlands culture found to the east. Aten (1984:74) summarizes his concept by saying, "it loosely connotes activities by populations on a geographic as well as a cultural periphery of the southeastern Woodlands."

Dee Ann Story (1990) has suggested that the culture of Southeast Texas is distinctive enough so as to merit a separate designation by the Late Prehistoric. The Mossy Grove cultural tradition is a heuristic concept based on technological similarities shared by groups in this region. The primary marker of this technological tradition is the plain, sandy-paste Goose Creek pottery that is found in this region from the Early Ceramic through Early Historic periods.

Ethnic affiliations for the region are not entirely clear. Aten (1983) has defined the Brazos Delta-West Bay, Galveston Bay, and Sabine Lake archaeological areas and suggests that they may correlate with the Historic territories of the Coco, Akokisa, and Atakapa groups, respectively. Similarly, historic reconstructions of the inland subregion suggest a number of possible group affiliations (Story 1990). The historic economic inland/coastal cycle of the Akokisa, which stretched from Galveston Bay to the San Jacinto River basin, may mean that archaeological materials in the Lake Conroe area are affiliated with this group. Alternately, these remains may be associated with the Bidais who occupied territory immediately to the north of the Akokisa groups. At this point in time, it is not possible to identify the cultural affiliation of the groups that inhabited the inland subregion. In part, this is a function of the dynamic nature of this region in which a number of cultural traditions met and diffused.

The Southeast Texas region is divided into inland and coastal margin subregions, which have archaeologically distinctive subsistence patterns, settlement patterns, and artifact types. Archaeological and historic evidence suggests that some groups exploited inland resources year-round, while other groups spent parts of the year both inland and on the coast.

Based on aspects of material culture, researchers have identified six archaeological time periods associated with Native Americans in the Southeast Texas region; in general, these include the Paleoindian, Archaic (with Early, Middle, and Late subdivisions), Ceramic, Late Prehistoric, Protohistoric, and Historic Indian. Archaeologists within the region agree on the general framework of cultural time periods, while disagreeing on the temporal boundaries of these periods. Patterson's (1995) chronology, for example, includes Early Paleoindian $(10,000-8,000 \quad$ B.C.), Late Paleoindian (8,000-5,000 B.C.), Early Archaic (5,000-3,000 B.C.), Middle Archaic (3,0001,500 B.C.), Late Archaic (1,500 B.C.-A.D. 100), Early Ceramic (A.D. 100-A.D. 600), Late Prehistoric (A.D. 600 to 1500), Protohistoric (A.D. 1500 to 1700), and the Historic Indian (A.D. 1700 to 1800) periods. In contrast, Ensor (1995) offers a Southeast Texas chronology that includes Paleoindian (10,000 to 8000 B.C.), Early Archaic (8000 to 5000 B.C.), Middle Archaic (5000 to 1000 B.C.), Late Archaic (1000 B.C. to A.D. 400), Early Ceramic (A.D. 400 to 800), and Late Ceramic (A.D. 800 to 1750). Despite these differences, the chronologies developed by researchers are based primarily on changes in projectile point 
technologies within the region and the introduction of pottery. It is generally recognized that a broad-based hunting and gathering lifestyle was utilized throughout all time periods.

\subsubsection{Paleoindian Period}

Evidence is sparse for Paleoindian habitation, and much of what is known about the period in the area comes from a compilation of materials gathered from the state of Texas and North America. At the close of the Pleistocene, large game hunters crossed the Bering Strait, and within a few millennia had penetrated into South America (Culberson 1993; Newcomb 1961). The Paleoindian people traveled in small bands (Culberson 1993) and were mega-fauna hunter-gatherers with the bulk of their meat protein derived from mammoths, mastodons, giant bison, and giant sloths. These groups carried with them an easily recognizable stone tool material culture, though admittedly, little is known about their wooden or bone tools and clothing types. The later Folsom Culture developed a very efficient toolkit that was apparently designed to be portable leading to theories that these people were following buffalo herds across the plains. However, the widespread use of Folsom technology suggests that the technology spread beyond the area for which it was initially designed. Isolated Paleoindian artifacts found across southeastern Texas include Clovis, Angostura, Scottsbluff, Meserve, Plainview, and Golondrina point types (Aten 1983).

The Transitional Archaic period begins about 9,000 years ago and ends around 7,500 years ago (Aten 1983; Story 1990). This stage is also poorly represented in the archaeological work in the area but isolated finds of Bell/Calf Creek, Early-Side Notched, and Early Expanding Stemmed dart points are attributed to this time period.

\subsubsection{Archaic Period}

With the retreat of the glaciers (the Hypsithermal period), the mega-fauna upon which the Paleoindian peoples depended gradually became extinct. This shift in food supply is seen as the pivotal transition point between the Paleo and Archaic periods (Biesaart et al. 1985; Culberson 1993; Newcomb 1961). Though dates often disagree (ranging from 8,000 B.C. marking the beginning of the Early Archaic [Culberson 1993], to Aten [1984] stating that the transition from Late Archaic to Late Prehistoric-Woodland began around A.D. 100), there are three progressive stages recognizable during the Archaic period: the Early, Middle, and Late.

Much of what is known about the Early Archaic peoples indicates that they were small, isolated bands of hunter-gatherers that remained in relatively restricted regions (Aten 1984). With the loss of the mega-fauna as a food source, the Early Archaic peoples adopted the hunting of smaller game such as bison and deer and increased their reliance on foraging (Culberson 1993). The material record fits the transitional makeup of this period because there was a dramatic shift from the large spear points of the Paleoindian period to a reliance on smaller dart type points. Diagnostic designs for this period are Dalton, San Patrice, Angostura, Golondrina, Merserve, Scottsbluff, Wells, Hoxie, Gower, Uvalde, Martindale, Bell, Andice, Baird, and Taylor (Turner and Hester 1993). These points are much more crudely made than their Paleo precursors but remain designed for use on a spear shaft.

The Middle Archaic period saw the largest growth in technology and in the number of stone tools utilized. Specialized tools appeared for the milling of wild plant foodstuffs (Culberson 1993) along with a large assortment of tools for food preparation and procurement. Gravers, scrapers, axes and choppers, knives, drills and polished stone tools, also known as ground stone tools, began to appear in large quantities (Newcomb 1961). Diagnostic points such as Gary, Kent, Palmillas, Nolan, Travis, Belvedere, Pedernales, Marshall, Williams, and Lange dominate the spectrum of dart points from the Middle Archaic period (Turner and Hester 1993; see also the Edwards Plateau 
Aspect [Newcomb 1961]). The advent of the atlat also seems to be placed within this period (Culberson 1993).

The Late Archaic period saw a dramatic increase in the population densities of Native American groups. Human habitation of areas rich in diverse flora and fauna intensified, as did the variety of materials and artifacts (Culberson 1993; Aten 1984). Late Archaic peoples began relying heavily on foraging tubers, berries, and nuts and hunting small game such as deer, rabbits, and raccoons, as well as fish and shellfish, and birds. Groups became socially more complex than earlier periods and the result was an increasing intercommunication with neighboring groups. Culberson (1993:55) states that a "Lapidary Industry" developed in which stone artifacts were made from exotic materials (jasper, hematite, quartz, shale, slate, etc.) acquired from sources great distances away. These materials were fashioned into an increasingly complex array of household goods such as celts, plummets, banner stones, mortars and pestles, and pendants; also, during this period there is an increase in the occurrence of sandstone bowls (Culberson 1993). Diagnostic points of this period are difficult to distinguish from those of the Middle Archaic. Gary and Kent points remain prevalent in southeast Texas, while other points such as Marcos, Montell, San Gabriel, Mahomet, Fairland, and Castroville also appear at times (Turner and Hester 1993).

The Archaic period in southeast Texas ends with the adoption of ceramic technology at the beginning of the Ceramic period. Patterson (1995) places the beginning of the Early Ceramic period on the Texas coast from 100600 A.D. Aten (1983) placed the appearance of pottery in the Galveston Bay area approximately 100 A.D. The ceramic chronology of the inland areas parallels that of the coast; however, it does not manifest until several centuries later. The inland areas generally lack the earliest ceramic types present in the coastal region as well as some of the later ceramic types (Aten 1983; Story 1990). As a result of trade networks or stylistic/manufacturing influences, it appears that ceramic traits moved from the coast to the inland areas and from the east to the west (Aten 1983).

\subsubsection{Late Prehistoric}

The transitional period between Late Archaic and Woodland-Late Prehistoric is a period marked by an intensification of group dynamics across Texas. The advent of the bow and arrow is believed by most (Aten 1984; Culberson 1993; Newcomb 1961) to be from this period, though some may place it later. Most importantly for archaeological investigations, the first signs of pottery begin to emerge at sites from this period (Aten 1983). Although the amount and variety of pottery intensifies during the Late Prehistoric, it is an excellent way of determining the terminus post quem of a site. Fishing, bison hunting, and the collection of wild flora intensifies beyond the level of the Late Archaic period during this stage, but there is no sufficient data to demonstrate the initial advent of sedentary agricultural. The diagnostic points of this period are Catahoula, Friley, Alba, and Bonham (Turner and Hester 1993).

The Late Prehistoric (also known as Woodland and Ceramic periods) continue from the end of the Archaic period to the Historic period ushered in by the Spanish Missions and AngloAmerican settlers. During this period, there is a shift to the almost total use of arrow points such as Perdiz and, later, Scallorn, and a wide variety of ceramic types. According to Aten (1984), there are nearly 18 different types of pottery from this period currently identified for the east Texas Coast alone based on temper, paste, and design.

Goose Creek and other sandy paste pottery types are often recovered from Ceramic period and Late Prehistoric sites throughout southeast Texas. Goose Creek appears in Aten's coastal chronology to greater or lesser extents in nearly every period, particularly Mayes Island, Turtle Bay, Round Lake, and the later Orcoquisac periods. Because of the predominance of sandy 
paste pottery across the region, Story (1990) has suggested the Mossy Grove Tradition as an encompassing cultural tradition for the area. Other ceramic forms that occur in the region include grog-tempered, stamped, and bonetempered pottery (Patterson 1996).

\subsubsection{Protohistoric Period to the Post- Contact Period}

It is during this period, that peoples known today as the Caddo, Attakapans, and Bidai, to name a few, are identifiable both culturally and materially. This is mostly due to the historical sources of the seventeenth through the nineteenth centuries that aid in the reconstruction of the past cultures in the area. In order to better understand the complexity of the region's cultures, researchers turn to historical sources to get an understanding of the peoples who first occupied the southeast Texas. Hernando De Soto encountered the Native Americans of the region during his expedition in 1542 (Hudson 1976); it was the first recorded meeting with the Caddo peoples. The first expeditions by La Salle in 1687 and the subsequent settlement in the eighteenth century by Europeans continued to document the presence of Native American groups in the area (Aten 1984). French traders and Spanish missionaries encountered the Hasinai, also known as the Neches Angelina, who became allies of the Spanish against the western Apache tribes (Newcomb 1961). The later historical sources identify the Hasinai as one of the two main groups in the area of eastern Texas that fall under the Caddo culture (the primary culture that dominated the Piney Woods area), the other of which is the Kadohadacho (La Vere 1998; Gregory 1986).

The loose cultural group, known as the Attakapans, dominated the majority of the land north of present-day Harris County in what is now Montgomery County. Their language group extended from the Gulf coast to the Trinity and San Jacinto Rivers and they had much in common with the coastal group known as the Karankawa (Aten 1984). The Attakapans were subdivided into regional groups. The Akokisas dwelled primarily on the shores of the Trinity and San Jacinto rivers. The Patiris group occupied the land north of the San Jacinto valley. The Bidai group dominated the Trinity Valley and to their north was the small group known as the Deadoso. Most of what is known about the Attakapans culture comes from the early accounts of the French explorer DeBellise. They are described as primarily hunter-gatherer groups who relied somewhat on agriculture and fishing (Sjoberg 1951).

In the seventeenth and eighteenth centuries, the Spanish and French used the Native American groups as pawns in the two nations' quest to settle the area (Newcomb 1961). Most destructive for all native groups in the region was the influx of European diseases. When Anglo-American settlers began moving into the area in mass around the 1850s, disease and warfare had decimated the groups to near extinction.

\subsection{Historical Context}

Fort Bend County was established on December 29, 1837, from parts of Austin, Brazoria, and Harrisburg counties. Richmond, which had been incorporated in May of that same year, was voted the county seat by the citizens of the new county. The area was originally settled in the 1820s as part of the land originally granted to Moses Austin by the Spanish colonial government and then reissued by the Mexican government after the Mexican Revolution (1810-1821). Of the 297 original grants, 53 of them were situated in the future Fort Bend County (Ott 2010).

In 1821, the first contingent of Stephen F. Austin's settlers anchored at the mouth of the Brazos River. A small party from this group continued 145 kilometers (90 miles) up the Brazos to a bend in the river. In November of 1822, a blockhouse was built at this location to protect the settlers from hostile Indians. Other settlers followed and a small community that came to be referred to as Fort Bend grew 
around the blockhouse. Fort Bend was located on one of the primary fords of the Brazos River and as such played a role in the troop movements during the Texas Revolution. The site was abandoned when Santa Anna's Mexican Army crossed the river in route to the battle of San Jacinto. When the area was resettled, the new community of Richmond was established (Leffler 2010).

Richmond became a regional trade center in the following decades, with barges and steamboats carrying the cotton, corn, and sugar produced in the region down the Brazos to Galveston (Leffler 2010). In 1853, the Buffalo Bayou, Brazos, and Colorado Railway proved a further boon to business connecting Stafford Point to Harrisburg. African slaves were essential to the plantation economy of region and by the 1850s, outnumbered the white inhabitants of the county. By the start of the Civil War, there were approximately 250,000 Africans held in captivity in Texas and the majority of these people were living on plantations in eastern Texas. Because of their economic and social dependency on slave labor, Fort Bend planters strongly supported the secession of the southern states from the United States of America (Ott 2010).

The final quarter of the nineteenth century witnessed a steady increase in the settlement and population of the county. Immigrants from Central Europe, including Czechs, Germans, Austrians, and Bohemians, established prosperous small farms on the lands once held by the large plantations. A number of settlements arose along the rail lines that stretched across the entire county. One such community, Rosenberg, grew at the junction were the Colorado and Santa Fe line crossed the Galveston, Harrisburg, and San Antonio line 5 kilometers (3 miles) west of Richmond. Rosenberg would grow to be the predominant town in the county surpassing Richmond in population in 1920 (Ott 2010).

The economy of Fort Bend in the nineteenth century focused on cotton, sugar, corn, and livestock production. In the 1890s, a onemillion-dollar sugar refinery was constructed in Sugar Land. The county also contains substantial amounts oil, gas, and sulfur deposits, which have played a major role in the economic development of the area (Ott 2010).

Fort Bend County's economic and social identities have revolved around farming and ranching since the earliest settlers arrived. Poor economic and agricultural conditions in the later part of the nineteenth century resulted in a movement toward farm tenancy. In 1925, 72 percent of farms in the County were operated on a tenancy basis. During the World War II years, the lure of jobs in urban centers and the military reduced the number and ratio of tenant farmers. More valuable uses of the farmland by home developments, industry, business, and commerce reduced the number of viable commercial farms. Until very recently, the development and transport of oil, gas, and sulfur have been at the heart of commercial ventures and industry in the county. As the City of Houston has expanded westward, a more diverse mix of commerce and industry has taken root. Property-development corporations and two high-technology corporations are the largest contributors to the county's tax coffers (Ott 2010). 


\subsection{FIELD METHODOLOGY}

This cultural resources investigation was designed to identify and assess new and already recorded cultural resources that may be impacted by the proposed project. Desktop assessment and modeling were performed prior to initiating field investigations in order to better understand cultural, environmental, and geological settings. Results of the desktop assessment were then used to develop the field methodology.

\subsection{Site File and Literature Review}

Site file research was initiated by reviewing records maintained by the Texas Archeological Research Laboratory (TARL) in Austin, Texas and by consulting online research archives maintained by the Texas Historical Commission (THC). Site file research resulted in a listing of all archaeological sites within 1.6 kilometers (1 mile) of the project area and all historic structures eligible for the National Register of Historic Places (NRHP) listing located adjacent to the project APE. Documentary research, including historical maps, USGS topographic maps, historical aerials, and land grants, was conducted in order to provide an understanding of the development and history of the project area, the surrounding area, and southeast Texas in general. This research then was used to prepare an overview history of the area and to provide an understanding of the contextual framework of local prehistory and history.

\subsection{Field Methods}

\subsubsection{Intensive Pedestrian Survey}

Shovel testing was carried out along four transects at 60-meter (200-foot) intervals. Subsurface testing consisted of the excavation of 30- by 30-centimeter (12- by 12 -inch) shovel tests. Vertical control was maintained by excavating each shovel test in 10-centimeter (4inch) levels. One wall of each shovel test was profiled, and the walls and floor of each shovel test were inspected for color or texture change potentially associated with the presence of cultural features. When possible, soils were screened through 0.64 -centimeter (0.25-inch) wire mesh; soils with high clay content were hand sorted in an effort to detect cultural materials in the soil matrix. Descriptions of soil texture and color followed standard terminology and the Munsell (2005) soil color charts. All the field data were recorded on appropriate field forms. All shovel tests were backfilled after excavation and documentation. The excavated shovel tests were placed on field maps and points were taken with Global Positioning System (GPS) if the strength of the signal permitted.

\subsubsection{Site Definition}

If new cultural resources were encountered, systematic steps would be taken to define their extent, limits, and general character within the confines of the APE. Additional delineation shovel tests would be excavated in four radiating directions at an interval of 10 meters (32.8 feet) within the confines of the APE. In general, two sterile shovel tests would be used to define a site's size and extent. At a minimum, between six and eight delineation shovel tests would be excavated unless surrounding landforms or topography suggested the presence of a natural site boundary.

For each cultural resource identified, including structures or other resources within or immediately adjacent to the APE, photographs would be taken of the general vicinity and of any visible features. A sketch map would be prepared showing site limits, feature locations, permanent landmarks, topographic and vegetation variations, sources of disturbances, and total number of tests performed within the site. Only diagnostic artifacts recovered from shovel tests would be collected. Locations of all positive tests were recorded with the GPS. 
If any architectural resources had been identified, these would have been recorded on corresponding field forms. Details of form, construction, material, style, condition, and alteration would be recorded both on the forms and photographically for each structure. All documentation would be reviewed by a qualified Architectural Historian who would decide if additional information or a personal field inspection was necessary at the survey level.

\subsection{Deep Testing}

Archaeological inspection for the deep impacts involved both monitoring and archaeological deep testing. Archaeological monitoring was accomplished by two monitors, present onsite while excavation and coring took place. Excavation was accomplished by a backhoe or track hoe to a depth of approximately 3 meters (10 feet). Archaeological monitors periodically halted excavation for sampling and screening of excavated back dirt at regular intervals. At least one soil sample was taken by shovel and screened using an 0.64 -centimeter (0.25-inch) wire mesh taken from each bucket at each pass of the backhoe; clay soils were hand sorted. The location and size of any in situ cultural deposits would have been recorded and mapped. If any artifacts or possible cultural lenses of bone, shell or charcoal had been observed in the walls of the excavation, or found during screening, construction excavation would have stopped, allowing archeologists time to document the find and draw profiles and take photographs.
As the construction schedule allowed, Gray \& Pape conducted more traditional archaeological deep testing by placing a series of trenches within the proposed footprint of each structure. Each structure measured approximately 36 meters ( 120 feet) long by 12 meters (40 feet) wide, therefore approximately five trenches, measuring approximately six meters (20 feet) by 1.5 meters (5 feet) were placed within each structure's proposed footprint as local conditions allowed. Vertical control was maintained by carefully scraping in 10 to 20 -centimeter (4 to 8 -inch) levels. One wall of each trench was profiled, and the walls and floors of each trench were photographed and inspected for color, texture, inclusions, and disturbances in an effort to identify any possible cultural features. Descriptions of soil texture and color followed standard terminology and the Munsell (2005) soil color charts.

The locations of all deep testing trenches excavated during the survey were recorded with a sub-meter accurate GPS data collector and recorded on field maps. Digital photography aided documentation of the existing conditions of the project area and fieldwork methods, with photograph locations recorded on field maps and logged with a GPS unit.

\subsection{Curation}

No diagnostic or non-diagnostic artifacts were collected in the course of the current survey. As a project permitted through the THC, however, Gray \& Pape submitted project records to the Center for Archaeological Studies at Texas State University in San Marcos, Texas. 


\subsection{RESULTS OF INVESTIGATIONS}

\subsection{Result of Site File and Literature Review}

A search of the Texas Archeological Sites Atlas, maintained by the THC determined that no previously identified archaeological sites, cemeteries, historical markers, or National Register properties are located within the project APE. The same research identified that nine previous cultural resource surveys had been conducted within the study radius of the project area, one of these surveys overlaps with the current APE. Fourteen previously recorded archaeological sites are located within the study radius, none of which are located within or immediately adjacent to the current APE (Figure 1-1).

\subsubsection{Previously Recorded Surveys}

The Texas Archeological Sites Atlas identifies nine previous cultural resource surveys conducted with 1.6 kilometers (1 mile) of the APE (Table 5-1). One of these surveys overlaps with the current APE. In 1985, a large area survey was sponsored by the Environmental Protection Agency (EPA) and the Department of
Housing and Urban Development. This survey included the entirety of the project area; however, no additional information was available on the Texas Archeological Sites Atlas concerning the methods or findings of this particular project.

\subsubsection{Previously Recorded Archaeological Sites}

According to a search of the Texas Archeological Sites Atlas, maintained by THC, 14 previously recorded archaeological sites are located within the 1.6-kilometer (1-mile) study radius of the project area (Table 5-2). No sites occur within the APE. The closest site to the APE is $41 \mathrm{FB} 104$, located 370 meters $(1,200 \mathrm{feet})$ to the south and recorded in 1985. The site was described as an early twentieth century tenant farm house. In addition to the wood frame house, there were also a chicken coop and outhouse (Bryan and Lisk 1985). The house was subsequently demolished during residential development of the area. All of the sites within the study radius of the APE consist of late nineteenth and early twentieth century homesites or historic scatters.

Table 5-1. Previously Recorded Area and Linear Surveys within 1.6 kilometers of the Proposed Project Area, Fort Bend County, Texas.

\begin{tabular}{|c|c|c|c|c|c|c|}
\hline Survey Type & $\begin{array}{c}\text { TAC Permit } \\
\# \\
\end{array}$ & $\begin{array}{c}\text { Investigating Firm/ } \\
\text { Agency }\end{array}$ & $\begin{array}{l}\text { Field Work } \\
\text { Date }\end{array}$ & $\begin{array}{l}\text { Report } \\
\text { Author }\end{array}$ & Sponsoring Agency & $\begin{array}{l}\text { Report at } \\
\text { THC }\end{array}$ \\
\hline Area & N/A & $\mathrm{N} / \mathrm{A}$ & $01 / 1985$ & $\mathrm{~N} / \mathrm{A}$ & EPA & $\mathrm{N} / \mathrm{A}$ \\
\hline Area & 4828 & $\begin{array}{c}\text { International } \\
\text { Archaeology \& Ecology }\end{array}$ & 03/2008 & D'Aigle & $\begin{array}{l}\text { Fort Bend County Levee } \\
\text { Improvement District }\end{array}$ & $04 / 2008$ \\
\hline Area & $\mathrm{N} / \mathrm{A}$ & HRA Gray \& Pape & $03 / 2015$ & Bludau & USACE & $09 / 2015$ \\
\hline Area & $\mathrm{N} / \mathrm{A}$ & $\begin{array}{l}\text { Moore Archeological } \\
\text { Consulting, Inc. (MAC) }\end{array}$ & 03/1996 & Moore et al. & USACE & 03/2008 \\
\hline Area & 4778 & $\begin{array}{l}\text { Raba-Kistner } \\
\text { Consultants }\end{array}$ & $01 / 2008$ & $\begin{array}{l}\text { Held \& } \\
\text { Darnell }\end{array}$ & City of Sugarland & $05 / 2008$ \\
\hline Area & 682 & $\begin{array}{c}\text { Espey, Huston and } \\
\text { Associates }\end{array}$ & 04/1988 & $\begin{array}{l}\text { Voellinger \& } \\
\text { Moore }\end{array}$ & City of Sugarland & 08/1988 \\
\hline Testing & 682 & $\begin{array}{l}\text { Espey, Huston and } \\
\text { Associates }\end{array}$ & 03/1989 & $\begin{array}{l}\text { Voellinger \& } \\
\text { Smyth }\end{array}$ & USACE & $01 / 1989$ \\
\hline
\end{tabular}




\begin{tabular}{|c|c|c|c|c|c|c|}
\hline Survey Type & $\begin{array}{c}\text { TAC Permit } \\
\#\end{array}$ & $\begin{array}{c}\text { Investigating Firm/ } \\
\text { Agency }\end{array}$ & $\begin{array}{c}\text { Field Work } \\
\text { Date }\end{array}$ & $\begin{array}{c}\text { Report } \\
\text { Author }\end{array}$ & $\begin{array}{c}\text { Sponsoring Agency } \\
\text { THC }\end{array}$ & $\begin{array}{c}\text { Report at } \\
\text { Area }\end{array}$ \\
3218 & Michael Baker Jr. Inc & $10 / 2003$ & Mooney et al. & $\begin{array}{c}\text { Texas Department of } \\
\text { Transportation }\end{array}$ & $09 / 2004$ \\
\hline Area & N/A & N/A & $10 / 1998$ & N/A & USACE & N/A \\
\hline
\end{tabular}

Table 5-2. Previously Recorded Archaeological Sites within 1.6 kilometers of the Proposed Project Area, Fort Bend County, Texas.

\begin{tabular}{|c|c|c|c|c|}
\hline Trinomial & Resource Type & Size (meters square) & Original Recorder(s) and Date & NRHP Status \\
\hline $41 \mathrm{FB} 103$ & $\begin{array}{c}\text { Early } 20^{\text {th }} \text { century } \\
\text { homesite }\end{array}$ & 22,500 & Lisk \& Freeman 1985 & Undetermined \\
\hline $41 F B 344$ & Historic scatter & N/A & Bludau 2015 & Undetermined \\
\hline $41 F B 110$ & $\begin{array}{c}\text { Early } 20^{\text {th }} \text { century } \\
\text { homesite }\end{array}$ & 7,000 & Fields \& Hannum 1985 & Undetermined \\
\hline $41 F B 112$ & Historic scatter & 2,000 & Fields \& Hannum 1985 & Undetermined \\
\hline $41 F B 113$ & Historic scatter & 1,000 & Fields \& Hannum 1985 & Undetermined \\
\hline $41 F B 111$ & Historic scatter & 2,025 & Fields \& Hannum 1985 & Undetermined \\
\hline $41 \mathrm{FB} 109$ & $\begin{array}{c}\text { Early } 20^{\text {th }} \text { century } \\
\text { homesite }\end{array}$ & 900 & Freeman 1985 & Undetermined \\
\hline $41 F B 104$ & $\begin{array}{c}\text { Early } 20^{\text {th }} \text { century } \\
\text { homesite }\end{array}$ & 675 & Bryan \& Lisk 1985 & Undetermined \\
\hline $41 F B 108$ & $\begin{array}{c}\text { Early } 20^{\text {th }} \text { century } \\
\text { homesite }\end{array}$ & 85 & Freeman 1985 & Undetermined \\
\hline $41 F B 243$ & Historic residence & 2,700 & Dureka 1996 & Ineligible \\
\hline $41 F B 238$ & Historic residence & 20,000 & Dureka 1996 & Ineligible \\
\hline $41 \mathrm{FB} 237$ & Historic residence & 12,000 & Dureka 1996 & Ineligible \\
\hline $41 \mathrm{FB} 241$ & Historic residence & 9,500 & Dureka 1996 & Ineligible \\
\hline $41 F B 178$ & Historic residence & 5,600 & Smyth 1988 & Undetermined \\
\hline
\end{tabular}

\subsection{Results of Field Investigations}

\subsubsection{Reconnaissance and Shovel Testing}

Intensive pedestrian survey, including shovel testing was carried out along the length of the APE except in areas of significant surface disturbance or inundation. A total of 32 shovel tests were excavated, five planned tests were left unexcavated due to inundation, and eight planned tests were left unexcavated due to significant surface disturbance (Figure 5-1). All shovel tests were negative for cultural material and encountered soil profiles were consistent with deep alluvial depositional soils mapped for the APE.
Intact soil profiles were largely consistent across the APE, with the majority of tests resembling Shovel Test A12 (Figure 5-2). The first 15 centimeters ( 6 inches) consisted of a light brown (7.5YR6/4) granular loamy sand, underlain by 10 centimeters ( 4 inches) of a brown (7.5YR4/2) sandy loam. Between 25 and 100 centimeters (10 and 40 inches) below the surface was a strong brown (7.5YR5/6) blocky sandy clay loam. This second stratigraphic unit was missing in some of the shovel tests to the west (A1, A4, A6, A7). As an example, in Shovel Test A4 the upper 15 centimeters ( 6 inches) were a brown (7.5YR5/4) granular loamy sand underlain by dark gray (7.5YR4/1) blocky sandy clay loam with brown (7.5YR5/4) mottling to the base of the shovel test at 65 centimeters (25 inches) below the surface. 


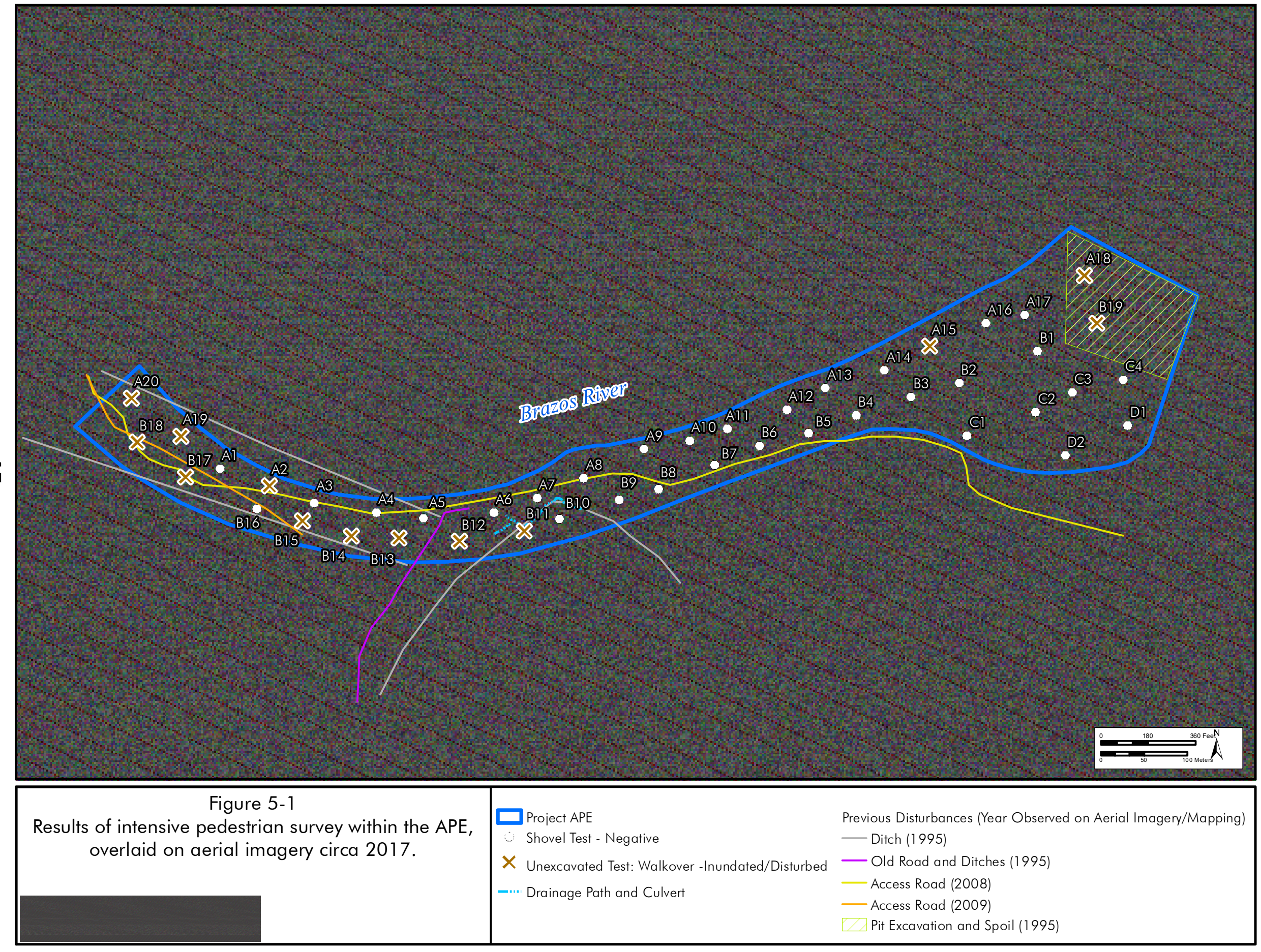



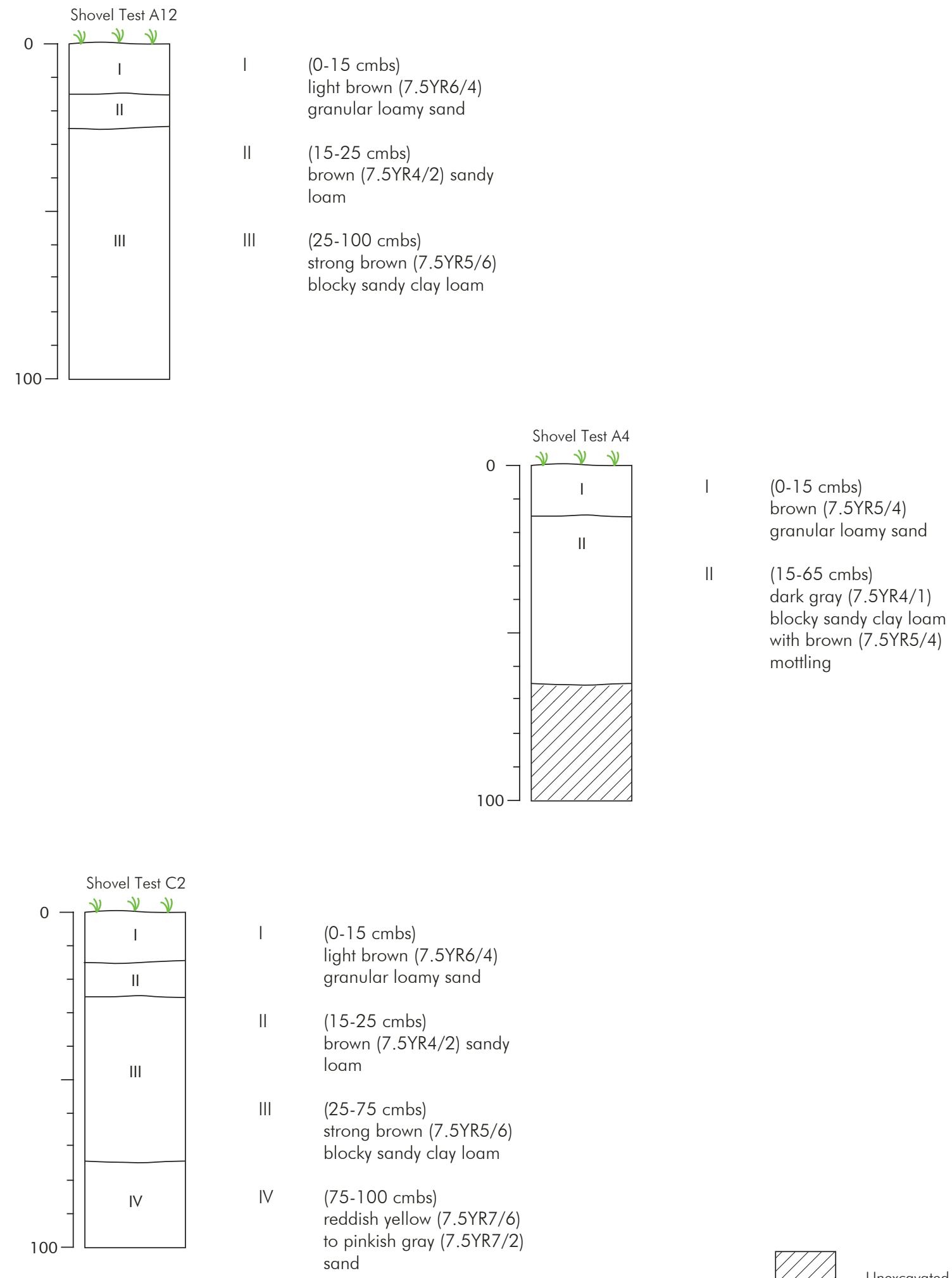

Representative soil profiles 
One notable variation in this profile was observed in three shovel tests near a noticeable ridgeline (B4, C2, D2) in which a fourth stratigraphic unit was encountered. In Shovel Test C2, the first 15 centimeters (6 inches) consisted of a light brown (7.5YR6/4) granular loamy sand, underlain by 10 centimeters (4 inches) of a brown (7.5YR4/2) sandy loam. Between 25 and 75 centimeters $(10$ and 30 inches), was a strong brown (7.5YR5/6) blocky sandy clay loam. Finally, extending to the base of the shovel test at 100 centimeters (40 inches) below the surface was a reddish yellow (7.5YR7/6) to pinkish gray (7.5YR7/2) sand (Figure 5-2).

In at least five shovel tests (A4, A5, A6, A9, A10), modern material including flagging tape, automobile glass, and road gravels were encountered at depths ranging from 10 to 85 centimeters (4 to 33 inches) below the surface. The road gravels encountered were similar to those observed in the surface of the levee road in the western portion of the APE.

Inundation resulted in five unexcavated shovel tests in the western third of the APE. The standing water appears to be caused by a combination of the existing levee system and an older raised roadbed that is preventing the water from draining (Figure 5-3). The areas of unexcavated shovel tests due to disturbance were concentrated in two locations. In the westernmost portion of the APE, was a partially graveled road with wide inundated ditches to either side (Figure 5-4). Historical aerial imagery had suggested that sand and gravel pit operations had previously impacted the eastern section of the APE. On the ground, the visible remains of this activity consisted of deep flooded ditches and large spoil piles (Figure 55).

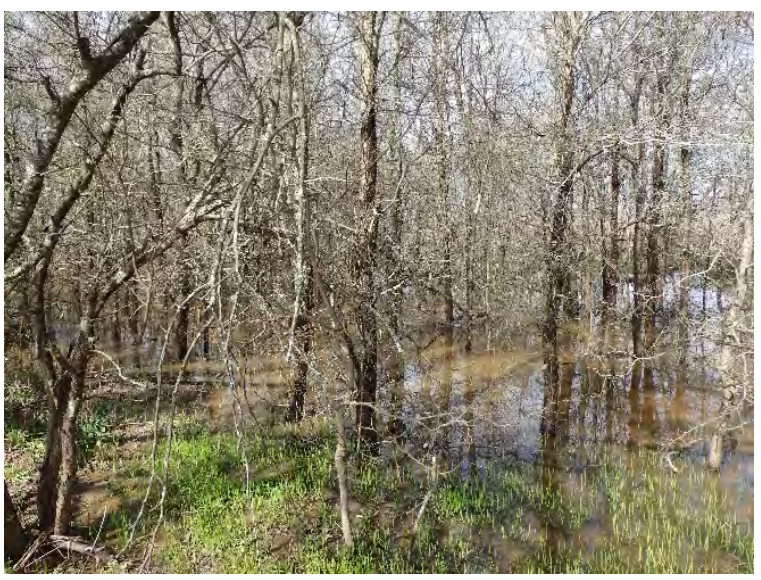

Figure 5-3. Inundated portion of the APE. View is to the northeast.

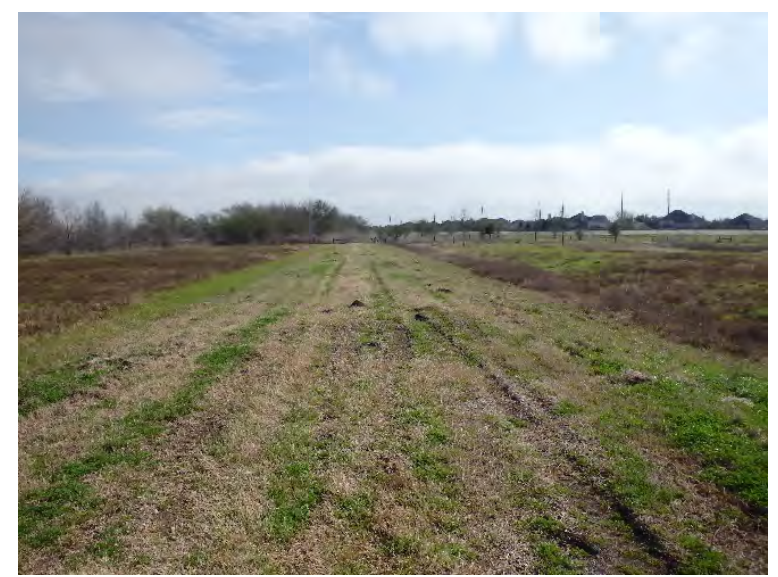

Figure 5-4. Levee road with inundated ditches at the western end of the APE. View is to the northwest.

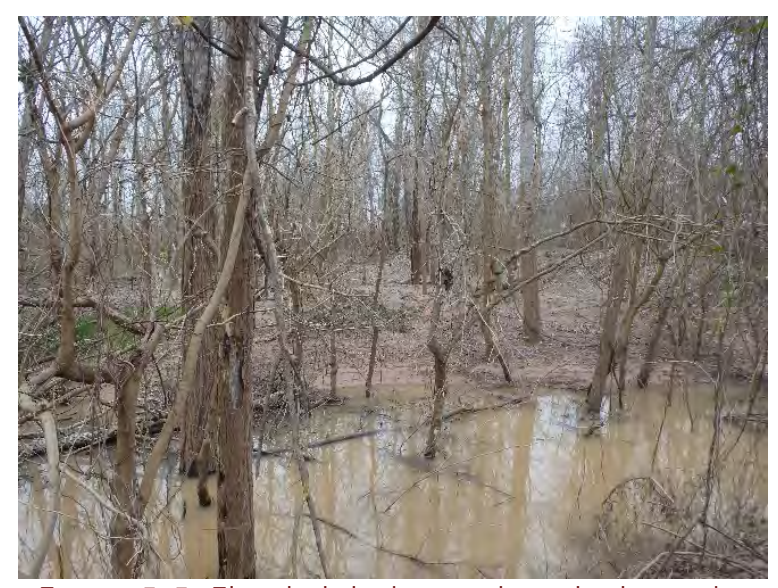

Figure 5-5. Flooded ditches and spoil piles in the eastern portion of the APE. View is to the southwest. 


\subsubsection{Deep Testing Results}

In order to test for deeply buried intact cultural resources, deep testing via mechanical trenching was carried out using a track hoe (Figures 5-6 and 5-7). A total of 22 trenches were excavated within the five remaining weir installation footprints (Figure 5-7). Five trenches were placed within each workspace with the exception of Structure 3, where there was a preexisting large drainage and culvert (Figure 5-6). None of the monitored or excavated trenches showed evidence of any artifacts or possible cultural lenses of bone, shell or charcoal.

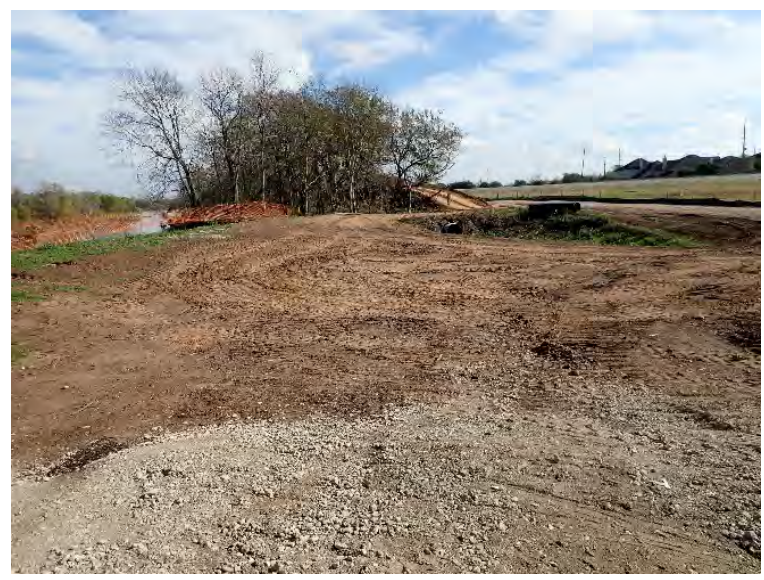

Figure 5-6. Workspace 3 with pre-existing culvert and drainage. View is to the east.

Soil observed during trenching were largely consistent across the project areas as well as with soils mapped for the area. In Structures 1 and 2, in the easternmost portion of the APE, soils were primarily sandy as seen in Trench 1.3. A surface layer 30 centimeters (12 inches) thick consisted of a brown (7.5YR4/4) sand partially disturbed by recent grading. This was underlain by a very dark brown (10YR2/2) sandy loam to a depth of 50 centimeters (20 inches) below the surface. Between 50 and 120 centimeters (20 and 47 inches) was a dark brown (7.5YR3/4) loose sand that gave way to a dark brown (7.5YR3/3) sandy clay that continued to a depth of 230 centimeters (90 inches) below the surface. A dark reddish brown (5YR3/2) clay was then observed to the base of the excavation at 300 centimeters (118 inches) below the surface.

Soils encountered in Workspace 3 and the workspaces to the west became increasingly clayey. A typical profile might be seen in Trench 5.1. The top 30 centimeters (12 inches) consisted of a dark yellowish brown (10YR3/4) sandy clay underlain by a very dark grayish brown (10YR3/2) sandy clay to a depth of 45 centimeters (18 inches) below the surface. Between 45 and 60 centimeters (18 and 24 inches) below the surface was a yellowish-brown sandy clay that was followed by a very dark grayish brown (10YR3/1) clay to a depth of 120 centimeters (47 inches) below the surface. A dark brown (7.5YR3/4) clay would then give way to a dark reddish brown (5YR3/2) clay at 180 centimeters (71 inches) below the surface, which continued to the base of the excavation at 300 centimeters ( 118 inches). 


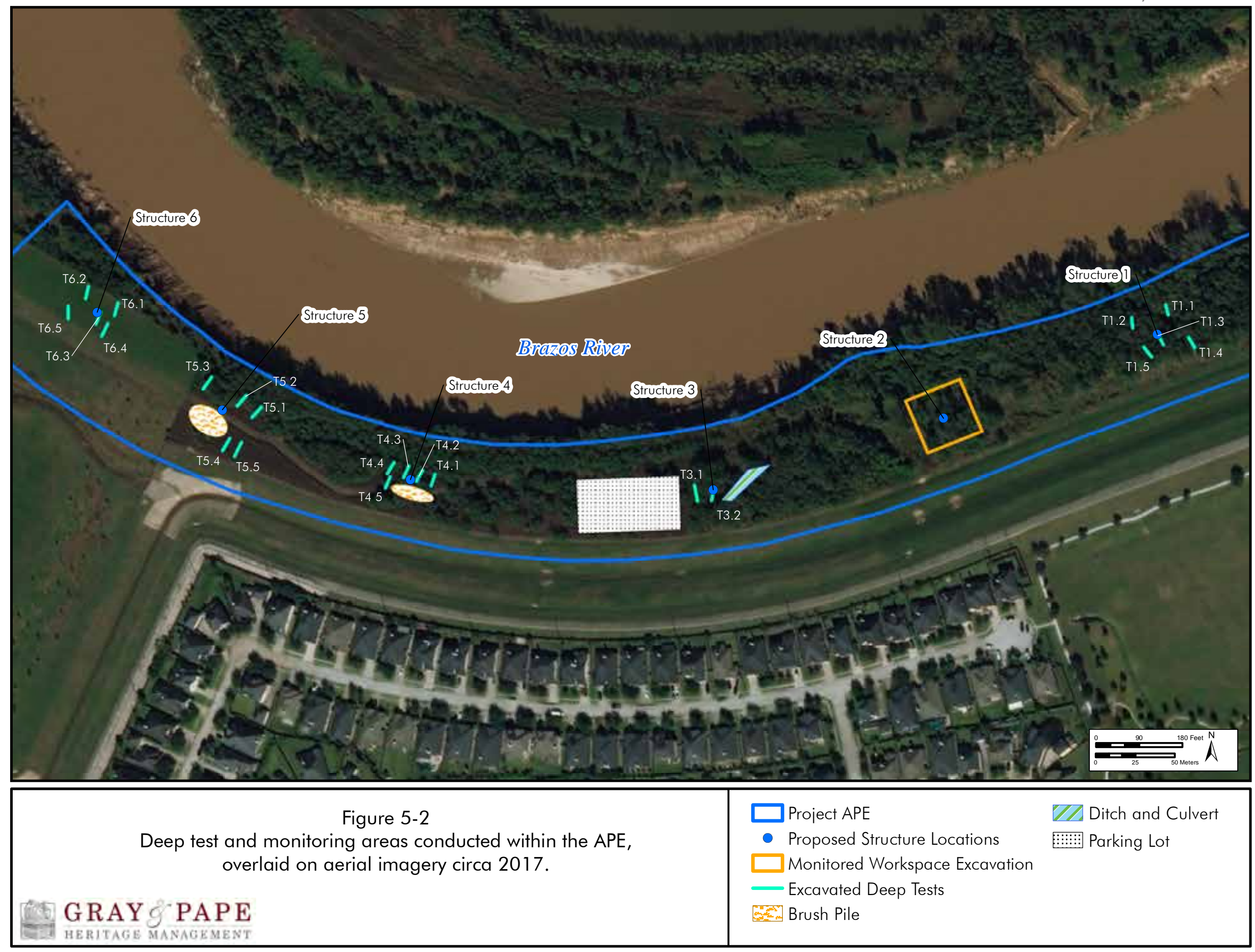




\subsection{CONCLUSIONS AND RECOMMENDATIONS}

This report summarizes the results of a cultural resources survey of an approximately 14.8hectare (36.6-acre) property in Fort Bend County, Texas, planned for a bank stabilization project by Gray \& Pape on behalf of their client, Berg-Oliver. The goals of the survey were to determine if the proposed project would affect any previously identified archaeological sites as defined by Section 106 of the NHPA of 1966, as amended (36 CFR 800), and to establish whether or not previously unidentified buried archaeological resources were located within the project's APE. Portions of the APE are on property owned by Fort Bend County MUD 121 , political subdivisions of the state, as such, a Texas Antiquities Permit (Permit Number 8734) was required prior to the commencement of fieldwork. All fieldwork and reporting activities were completed with reference to state (the Antiquities Code of Texas) and federal (NHPA) guidelines.

Prior to fieldwork mobilization, a background literature and site file search were conducted to identify the presence of recorded sites and previous cultural resource surveys within or near the APE. The search indicated that no previously identified archaeological sites, cemeteries, historical markers, or National Register properties are located within the project APE. The same research identified that nine previous cultural resource surveys had been conducted within the study radius of the project area, one of which overlapped with the current APE. In addition, fourteen previously recorded archaeological sites are located within the study radius, none of which are located within or immediately adjacent to the current APE.

Field investigations consisted of a combination of pedestrian survey and subsurface testing, resulting in the excavation of 32 shovel tests. Five planned tests were left unexcavated due to inundation, and eight planned tests were left unexcavated due to significant surface disturbance All shovel tests were negative for cultural resource material and no historic-age resources were identified during survey. Deep testing, by means of mechanical excavation, was carried out in five areas anticipated to have deep impacts from the proposed bank stabilization project. A sixth area was monitored during construction. A total of 22 trenches were excavated. No buried features or deeply buried paleosols were encountered.

Gray \& Pape archaeologists are of the opinion that the shovel test survey and deep testing completed within the APE has adequately assessed the potential for surface and near surface intact, significant cultural resources, as well as determining the potential for deeply buried resources or paleosols.

No artifacts or cultural features were encountered during the course of the survey, and no new archaeological sites were identified. No negative impacts on any previously identified sites are anticipated from the proposed project. Based on these results, Gray \& Pape recommends that no further cultural work be required and that the project be cleared to proceed as planned. 


\subsection{REFERENCES CITED}

Abbott, James T.

2001 Houston Area Geoarcheology; A Framework for Archeological Investigation, Interpretation, and Cultural Resource Management in the Houston Highway District. Texas

Department of Transportation, Environmental Affairs Division.

Aten, Lawrence $\mathrm{E}$.

1983 Indians of the Upper Texas Coast. Academic Press, New York.

1984 Woodland Cultures on the Texas Coast. In Perspective on Gulf Coast History, edited by Dave D. Davis, pp. 72-93. Ripley P. Bullen Monographs in Anthropology and History, No. 5. Florida State Museum, University Press of Florida, Gainesville.

Barnes, V.E.

1982 Geologic Atlas of Texas, Houston Sheet. Bureau of Economic Geology, University of Texas at Austin.

Biesaart, Lynne A., Wayne R. Robertson, and Lisa Springs

1985 Prehistoric Archaeological Sites in Texas: A Statistical Overview. Office of the State Archaeological Report 28. Texas Historical Commission, Austin.

Blair, W.F.

1950 The Biotic Provinces of Texas. Texas Journal of Science. 2:93-117.

Bryan, Bill and Susan Lisk

1985 Texas Archeological Site Form for Site 41FB104. Texas Archeological Sites Atlas. https://atlas.thc.state.tx.us. Accessed January 16, 2019.

Culberson, Linda C.

1993 Arrowheads and Spear Points in the Prehistoric Southeast: A Guide to Understanding Cultural Artifacts. University Press of Mississippi, Jackson.

Ensor, H.B.

1995 Archeological Test Excavations at Four Shell Midden Sites in the Wallisville Lake Project Area, Chambers and Liberty Counties, Texas. Geo-Marine, Plano.

Gilmer, Anastasia

2015 A Cultural Resource Survey of a 5.8-acre Potential Fort Bend County Tract, Fort Bend County, Texas. Moore Archeological Consulting, Inc., Houston.

Google, Inc.

2019 Google Earth Aerial Images: 1995, 2002-2017. Accessed January 13, 2019.

Gregory, H.F.

1986 The Southern Caddo: An Anthology. Garland Publishing: New York.

Griffith, Glen, Sandy Bryce, James Omernik, and Anne Rogers

2007 Ecoregions of Texas. Texas Commission on Environmental Quality. Austin. 
Holloway, Vance T.

1997 Paleoindian Geoarchaeology of the Southern High Plains. The University of Texas Press, Austin.

Hudson, Charles

1976 The Southeastern Indians. The University of Tennessee Press, Nashville.

La Vere, David

1998 The Caddo Chiefdoms: Caddo Economics and Politics, 700-1835. The University of Nebraska Press, Lincoln.

Leffler, John

2010 Richmond, Handbook of TX. Online. https://www.tshaonline.org/handbook/online/articles/RR/hfr4.html. Accessed January 13, 2017.

Mowery, Irvin C., Gordon S. McKee, Francisco Matanzo, and Everett Francis

1960 Soil Survey of Fort Bend County, Texas. United States Department of Agriculture Soil Conservation Service, Washington D.C.

Munsell Soil Color Chart (Musell)

2005 Revised Edition. Macbeth Division of Kollmorgan Instruments Corporoation.

Nationwide Environmental Title Research, LLC (NETR) Online

2019 Sugarland, TX 7.5 Minute Quadrangle Topographic Map, 1: 24,000 (1957, 1973, 1981, 1987, 1999, 2013, 2016). Aerial images (1953, 1968, 1995, 2002, 2004, 2008, 2010, 2012, 2014). http://www.historicaerials.com. Accessed January 13, 2019.

Newcomb, W.W. Jr.

1961 The Indians of Texas From Prehistoric to Modern Times. The University of Texas Press, Austin.

Ott, Virginia Laird 2010 Fort Bend County. Handbook of Texas Online. https://tshaonline.org/handbook/online/articles/hcf07. Accessed January 13, 2018.

Patterson, Leland

1995 The Archeology of Southeast Texas. Bulletin of the Texas Archeological Society 66:239264.

1996 Southeast Texas Archeology. Report No. 12, Houston Archeological Society

Shafer, Harry J.

1975 Comments on the Woodland Cultures of Texas. Bulletin of the Texas Archeological Society, 46:249-254.

Sjoberg, A.A.

1951 The Bidai Indians of Southeastern Texas. Southwestern Journal of Anthropology 7(4). 
Soil Survey Staff, Natural Resources Conservation Service, United States Department of Agriculture (SSS NRCS USDA)

2019 Web Soil Survey. Available URL:

http://websoilsurvey.nrcs.usda.gov/app/WebSoilSurvey.aspx . Accessed January 15, 2019.

Story, Dee Ann

1990 Cultural History of the Native Americans. In The Archeology and Bioarcheology of the Gulf Coastal Plain 1: 163-366. 2 vols. Research Series No. 38. Arkansas Archeological Survey, Fayettville.

Turner, E.S. and T.R. Hester

1993 A Field Guide to Stone Artifacts of Texas Indians, 2nd Edition. Texas Monthly Field Guide Series. Gulf Publishing Co., Houston

United States Army Corps of Engineers (USACE)

1929 Tactical Map Sugarland Quadrangle. Perry-Castaneda Library Map Collection, The University of Texas at Austin. www.lib.utexas.edu/maps/topo/texas/txu-pclmaps-topo-txsugarland-1915.jpg. Accessed July 17, 2017.

2014 Brazos River Erosion Management Project (BREM) Briefing Paper. USACE, Washington D.C.

United States Geological Survey (USGS)

1980 Sugarland, Texas Quadrangle (7.5 minute). USGS, Washington D.C.

Van Siclen, D.C.

1991 Surficial Geology of the Houston Area: An Offlapping Series of Pleistocene (\& Pliocene) Highest Sea Level Fluviodeltaic Sequences. Transactions of the Gulf Coast Association of Geological Societies, 41:651-666.

Waters, Michael

1992 Principles of Geoarchaeology: A North American Perspective. The University of Arizona Press, Tucson.

Waters, Michael and Lee Nordt

1995 Late Quaternary Floodplain History of the Brazos River in East-Central Texas. Quaternary Research 43:311-319. 


\section{APPENDIX A}

TRENCH TABLES 


\begin{tabular}{|c|c|c|}
\hline $\begin{array}{l}\text { Trench } \\
\text { Number }\end{array}$ & Soil Description & Comments \\
\hline \multirow{5}{*}{ Trench 1.1} & $\begin{array}{l}\text { Strat I (0-30 cmbs) - brown (7.5YR4/4) sand with signs of } \\
\text { disturbance from recent grading }\end{array}$ & \\
\hline & Strat II (30-40 cmbs) - very dark brown (10YR2/2) sandy loam & \\
\hline & Strat III (40-80 cmbs) - dark brown (7.5YR3/4) loose sand & \\
\hline & Strat IV (80-260 cmbs) - dark brown $(7.5$ YR3/3) sandy clay & \\
\hline & Strat V (260-315 cmbs) - dark reddish brown (5YR3/2) clay & \\
\hline \multirow{5}{*}{ Trench 1.2} & $\begin{array}{l}\text { Strat I (0-50 cmbs) - brown (7.5YR4/4) sand with signs of } \\
\text { disturbance from recent grading }\end{array}$ & \\
\hline & Strat II (50-60 cmbs) - very dark brown (10YR2/2) sandy loam & \\
\hline & Strat III $(60-110 \mathrm{cmbs})$ - dark brown $(7.5 \mathrm{YR} 3 / 4)$ loose sand & \\
\hline & Strat IV (1 $10-220 \mathrm{cmbs})$ - dark brown (7.5YR3/3) sandy clay & \\
\hline & Strat V (220-280 cmbs) - dark reddish brown (5YR3/2) clay & \\
\hline \multirow{5}{*}{ Trench 1.3} & $\begin{array}{l}\text { Strat I (0-40 cmbs) - brown (7.5YR4/4) sand with signs of } \\
\text { disturbance from recent grading }\end{array}$ & \\
\hline & Strat II (40-50 cmbs) - very dark brown (10YR2/2) sandy loam & \\
\hline & Strat III (50-120 cmbs) - dark brown (7.5YR3/4) loose sand & \\
\hline & Strat IV (120-230 cmbs) - dark brown (7.5YR3/3) sandy clay & \\
\hline & Strat V (230-300 cmbs) - dark reddish brown (5YR3/2) clay & \\
\hline \multirow{3}{*}{ Trench 1.4} & $\begin{array}{l}\text { Strat I (0-30 cmbs) - brown (7.5YR4/4) and very dark brown } \\
\text { (7.5YR4/4) sandy clay loam, heavily disturbed }\end{array}$ & \\
\hline & Strat II (30-160 cmbs) - yellowish brown (10YR5/6) sandy clay & \\
\hline & Strat III (160-240 cmbs) - dark reddish brown (5YR3/2) clay & \\
\hline \multirow{5}{*}{ Trench 1.5} & $\begin{array}{l}\text { Strat I (0-40 cmbs) - brown (7.5YR4/4) sand with signs of } \\
\text { disturbance from recent grading }\end{array}$ & \\
\hline & Strat II (40-50 cmbs) - very dark brown (10YR2/2) sandy loam & \\
\hline & Strat III (50-70cmbs) - dark brown (7.5YR3/4) loose sand & \\
\hline & Strat IV $(70-200 \mathrm{cmbs})$ - dark brown (7.5YR3/3) sandy clay & \\
\hline & Strat V $(200-300 \mathrm{cmbs})$ - dark reddish brown (5YR3/2) clay & \\
\hline \multirow{4}{*}{ Trench 3.1} & Strat I (0-30 cmbs) - dark yellowish brown (10YR3/4) sandy clay & \\
\hline & Strat II (30-90 cmbs) - black (10YR2/1) sandy clay & \\
\hline & Strat III (90-130 cmbs) - black (10YR2/1) clay & \\
\hline & Strat IV (130-230 cmbs) - dark reddish brown (5YR3/2) clay & \\
\hline \multirow{4}{*}{ Trench 3.2} & Strat I $(0-30 \mathrm{cmbs})$ - dark yellowish brown (10YR3/4) sandy clay & \\
\hline & Strat II (30-70 cmbs) - black (10YR2/1) sandy clay & \\
\hline & Strat III $(70-150 \mathrm{cmbs})$ - black (10YR2/1) clay & \\
\hline & Strat IV (150-270 cmbs) - dark reddish brown (5YR3/2) clay & \\
\hline \multirow{5}{*}{ Trench 4.1} & $\begin{array}{l}\text { Strat I (0-20 cmbs) - dark yellowish brown (10YR3/4) and black } \\
\text { (10YR2/1) disturbed sandy clay }\end{array}$ & \\
\hline & Strat II $(20-70 \mathrm{cmbs})$ very dark gray (10YR3/1) sandy clay & \\
\hline & Strat III $(70-90 \mathrm{cmbs})$ - dark brown (7.5YR3/4) sandy clay & \\
\hline & Strat IV (90-150 cmbs) - black (10YR2/1) clay & \\
\hline & Strat V (150-300 cmbs) - dark reddish brown (5YR3/2) clay & \\
\hline \multirow[t]{2}{*}{ Trench 4.2} & $\begin{array}{l}\text { Strat I (0-20 cmbs) - dark yellowish brown (10YR3/4) and black } \\
\text { (10YR2/1) disturbed sandy clay }\end{array}$ & \\
\hline & Strat II (20-40 cmbs) - dark reddish brown (5YR3/4) sandy clay & \\
\hline
\end{tabular}




\begin{tabular}{|c|c|c|}
\hline $\begin{array}{l}\text { Trench } \\
\text { Number }\end{array}$ & Soil Description & Comments \\
\hline & $\begin{array}{l}\text { Strat III (40-100 cmbs) - very dark grayish brown (10YR3/2) clay } \\
\text { with yellowish brown (10YR5/6) sandy films }\end{array}$ & \\
\hline & Strat IV $(100-260 \mathrm{cmbs})$ - dark brown $(7.5 Y R 3 / 4)$ clay & \\
\hline & Strat V (260-310 cmbs) - dark reddish brown (5YR3/2) clay & \\
\hline \multirow{4}{*}{ Trench 4.3} & Strat I (0-60 cmbs) - dark yellowish brown (10YR3/4) sandy clay & \\
\hline & Strat II (60-80 cmbs) - yellowish brown (10YR5/6) sandy clay & \\
\hline & Strat III (80-240 cmbs) - dark brown (7.5YR3/4) clay & \\
\hline & Strat IV (240-280 cmbs) - dark reddish brown (5YR3/2) clay & \\
\hline \multirow{6}{*}{ Trench 4.4} & Strat I (0-20 cmbs) - dark yellowish brown (10YR3/4) sandy clay & \\
\hline & $\begin{array}{l}\text { Strat II (20-50 cmbs) - very dark grayish brown (10YR3/2) sandy } \\
\text { clay }\end{array}$ & \\
\hline & Strat III $(50-70 \mathrm{cmbs})$ - yellowish brown (10YR5/6) sandy clay & \\
\hline & Strat IV (70-120 cmbs) - very dark gray (10YR3/1) clay & \\
\hline & Strat V $(120-200 \mathrm{cmbs})-$ dark brown $(7.5 Y R 3 / 4)$ clay & \\
\hline & Strat VI (200-300 cmbs) - dark reddish brown (5YR3/2) clay & \\
\hline \multirow{5}{*}{ Trench 4.5} & Strat I (0-20 cmbs) - dark yellowish brown (10YR3/4) sandy clay & \\
\hline & $\begin{array}{l}\text { Strat II (20-70 cmbs) - very dark grayish brown (10YR3/2) sandy } \\
\text { clay }\end{array}$ & \\
\hline & Strat III (70-90 cmbs) - yellowish brown (10YR5/6) sandy clay & \\
\hline & Strat IV $(90-150 \mathrm{cmbs})$ - very dark gray $(10 Y R 3 / 1)$ clay & \\
\hline & Strat V (150-280 cmbs) - dark reddish brown (5YR3/2) clay & \\
\hline \multirow{6}{*}{ Trench 5.1} & Strat I (0-30 cmbs) - dark yellowish brown (10YR3/4) sandy clay & \\
\hline & $\begin{array}{l}\text { Strat II (30-45 cmbs) - very dark grayish brown (10YR3/2) sandy } \\
\text { clay }\end{array}$ & \\
\hline & Strat III (45-60 cmbs) - yellowish brown (10YR5/6) sandy clay & \\
\hline & Strat IV $(60-120 \mathrm{cmbs})$ - very dark gray $(10 Y R 3 / 1)$ clay & \\
\hline & Strat V (120-180 cmbs) - dark brown (7.5YR3/4) clay & \\
\hline & Strat VI (180-300 cmbs) - dark reddish brown (5YR3/2) clay & \\
\hline \multirow{4}{*}{ Trench 5.2} & Strat I (0-40 cmbs) - dark yellowish brown (10YR3/4) sandy clay & \\
\hline & $\begin{array}{l}\text { Strat II (40-1 } 10 \mathrm{cmbs}) \text { - very dark grayish brown (10YR3/2) sandy } \\
\text { clay }\end{array}$ & \\
\hline & Strat III (1 1 0-200 cmbs) - dark brown (7.5YR3/4) clay & \\
\hline & Strat IV (200-240 cmbs) - dark reddish brown (5YR3/2) clay & \\
\hline \multirow{4}{*}{ Trench 5.3} & Strat I (0-20 cmbs) - dark yellowish brown (10YR3/4) sandy clay & \\
\hline & $\begin{array}{l}\text { Strat II (20-60 cmbs) - very dark grayish brown (10YR3/2) sandy } \\
\text { clay }\end{array}$ & \\
\hline & Strat III (60-140 cmbs) - dark brown (7.5YR3/4) clay & \\
\hline & Strat IV (140-300 cmbs) - dark reddish brown (5YR3/2) clay & \\
\hline \multirow{5}{*}{ Trench 5.4} & Strat I (0-50 cmbs) - dark yellowish brown (10YR3/4) sandy clay & \\
\hline & Strat II (50-70 cmbs) - yellowish brown (10YR5/6) sandy clay & \\
\hline & Strat III (70-1 $10 \mathrm{cmbs})$ - very dark grayish brown (10YR3/2) clay & \\
\hline & Strat IV (1 $10-200 \mathrm{cmbs})$ - dark brown (7.5YR3/4) clay & \\
\hline & Strat V (200-300 cmbs) - dark reddish brown (5YR3/2) clay & \\
\hline \multirow{2}{*}{ Trench 5.5} & Strat I (0-30 cmbs) - dark yellowish brown (10YR3/4) sandy clay & \\
\hline & Strat II (30-80 cmbs) - yellowish brown (10YR5/6) sandy clay & \\
\hline
\end{tabular}




\begin{tabular}{|c|c|c|}
\hline $\begin{array}{l}\text { Trench } \\
\text { Number }\end{array}$ & Soil Description & Comments \\
\hline & Strat III (80-140 cmbs) - very dark grayish brown (10YR3/2) clay & $\begin{array}{l}\text { Localized root } \\
\text { burn }\end{array}$ \\
\hline & Strat IV (140-200 cmbs) - dark brown (7.5YR3/4) clay & \\
\hline & Strat V (200-280 cmbs) - dark reddish brown (5YR3/2) clay & \\
\hline \multirow{5}{*}{ Trench 6.1} & $\begin{array}{l}\text { Strat I (0-30 cmbs) - dark yellowish brown (10YR3/4) sandy clay } \\
\text { loam }\end{array}$ & \\
\hline & Strat II (30-55 cmbs) - strong brown (7.5YR5/6) sandy clay & \\
\hline & Strat III (55-90 cmbs) - very dark grayish brown (10YR3/2) clay & \\
\hline & Strat IV $(90-190 \mathrm{cmbs})$ - dark brown $(7.5 \mathrm{YR} 3 / 4)$ clay & \\
\hline & Strat V (190-250 cmbs) - dark reddish brown (5YR3/2) clay & \\
\hline \multirow{4}{*}{ Trench 6.2} & $\begin{array}{l}\text { Strat I (0-40 cmbs) - dark yellowish brown (10YR3/4) sandy clay } \\
\text { loam }\end{array}$ & \\
\hline & Strat II $(40-80 \mathrm{cmbs})$ - strong brown $(7.5 Y R 5 / 6)$ sandy clay & \\
\hline & Strat III (80-180 cmbs) - dark brown (7.5YR3/4) clay & \\
\hline & Strat V (180-240 cmbs) - dark reddish brown (5YR3/2) clay & \\
\hline \multirow{4}{*}{ Trench 6.3} & $\begin{array}{l}\text { Strat I (0-30 cmbs) - dark yellowish brown (10YR3/4) sandy clay } \\
\text { loam }\end{array}$ & \\
\hline & Strat II (30-70 cmbs) - strong brown (7.5YR5/6) sandy clay & \\
\hline & Strat III $(70-160 \mathrm{cmbs})$ - dark brown $(7.5 Y R 3 / 4)$ clay & \\
\hline & Strat V (160-240 cmbs) - dark reddish brown (5YR3/2) clay & \\
\hline \multirow{4}{*}{ Trench 6.4} & $\begin{array}{l}\text { Strat I (0-30 cmbs) - dark yellowish brown (10YR3/4) sandy clay } \\
\text { loam }\end{array}$ & \\
\hline & Strat II (30-85 cmbs) - strong brown (7.5YR5/6) sandy clay & \\
\hline & Strat III $(85-170 \mathrm{cmbs})$ - dark brown $(7.5 Y R 3 / 4)$ clay & \\
\hline & Strat V (170-280 cmbs) - dark reddish brown (5YR3/2) clay & \\
\hline \multirow{4}{*}{ Trench 6.5} & $\begin{array}{l}\text { Strat I (0-30 cmbs) - dark yellowish brown (10YR3/4) sandy clay } \\
\text { loam }\end{array}$ & \\
\hline & Strat II $(30-60 \mathrm{cmbs})$ - strong brown $(7.5 Y$ Y 5/6) sandy clay & \\
\hline & Strat III (60-165 cmbs) - dark brown (7.5YR3/4) clay & \\
\hline & Strat V $(165-280 \mathrm{cmbs})$ - dark reddish brown $(5 Y \mathrm{YR} 3 / 2)$ clay & \\
\hline
\end{tabular}




\section{APPENDIX B}

TRENCH PROFILE PHOTOGRAPHS 


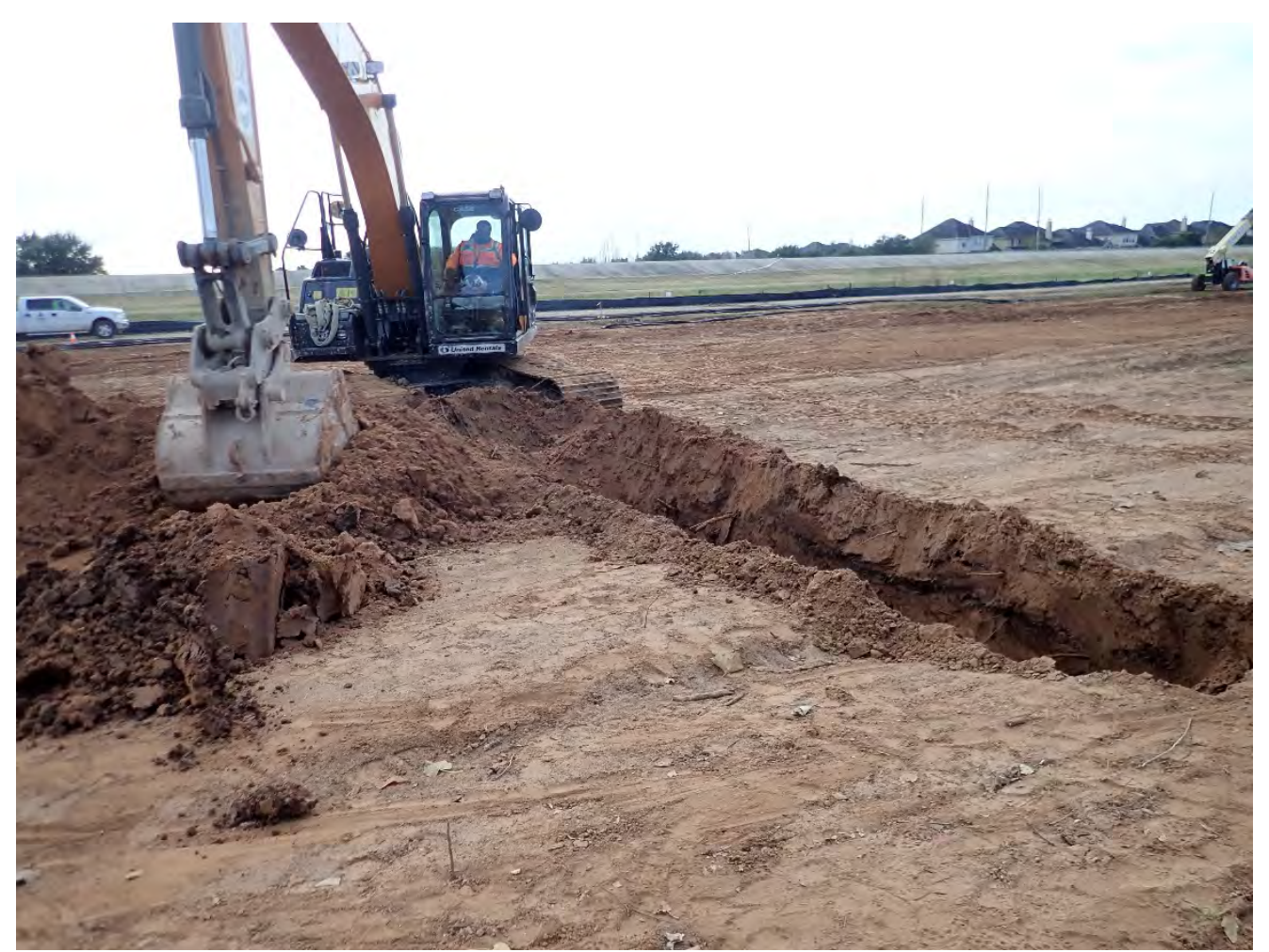

Figure B1. Overview of the Structure 1 location with trackhoe in operation. View is to the south.

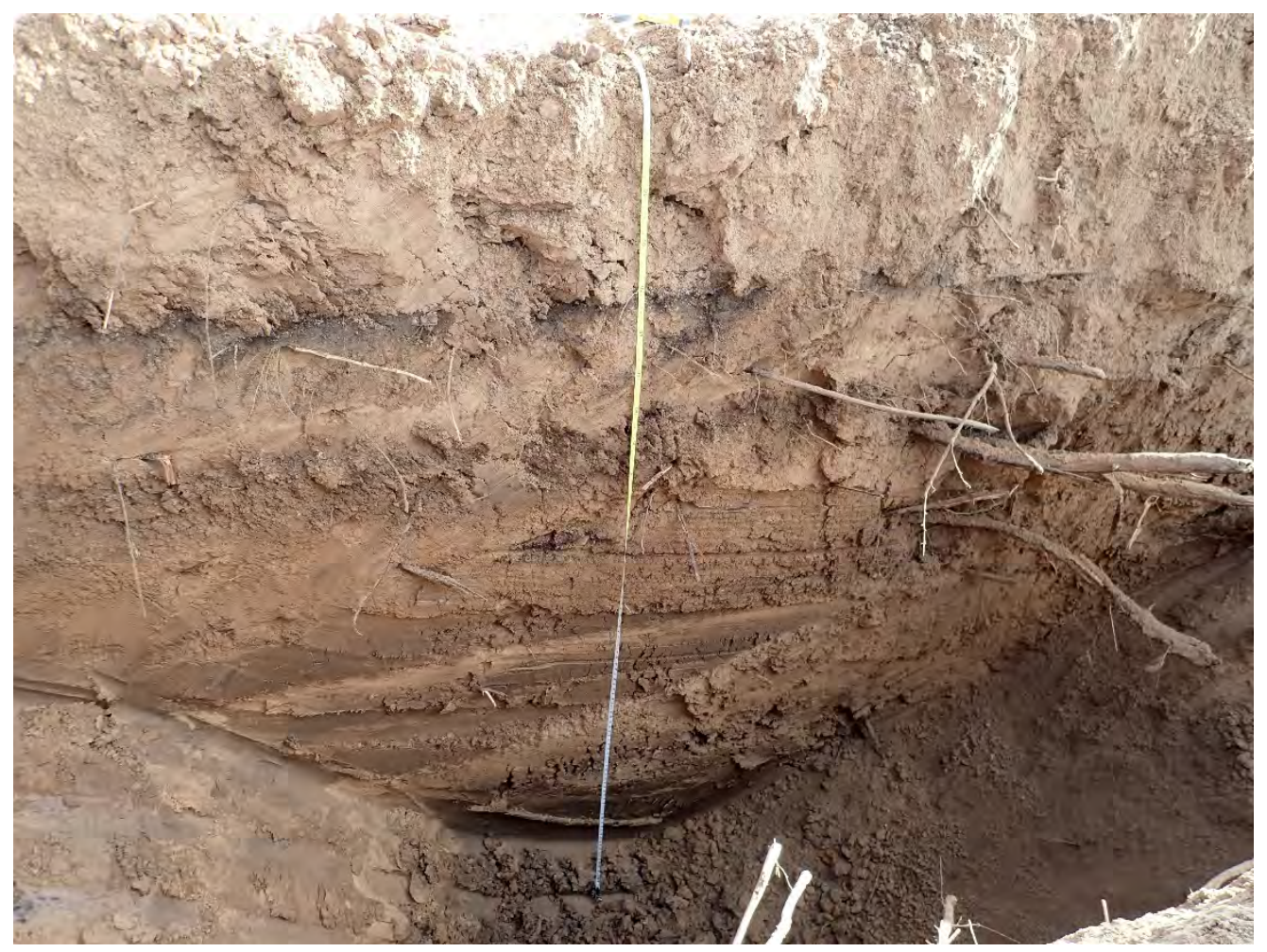

Figure B2. East wall profile of T1.1. 


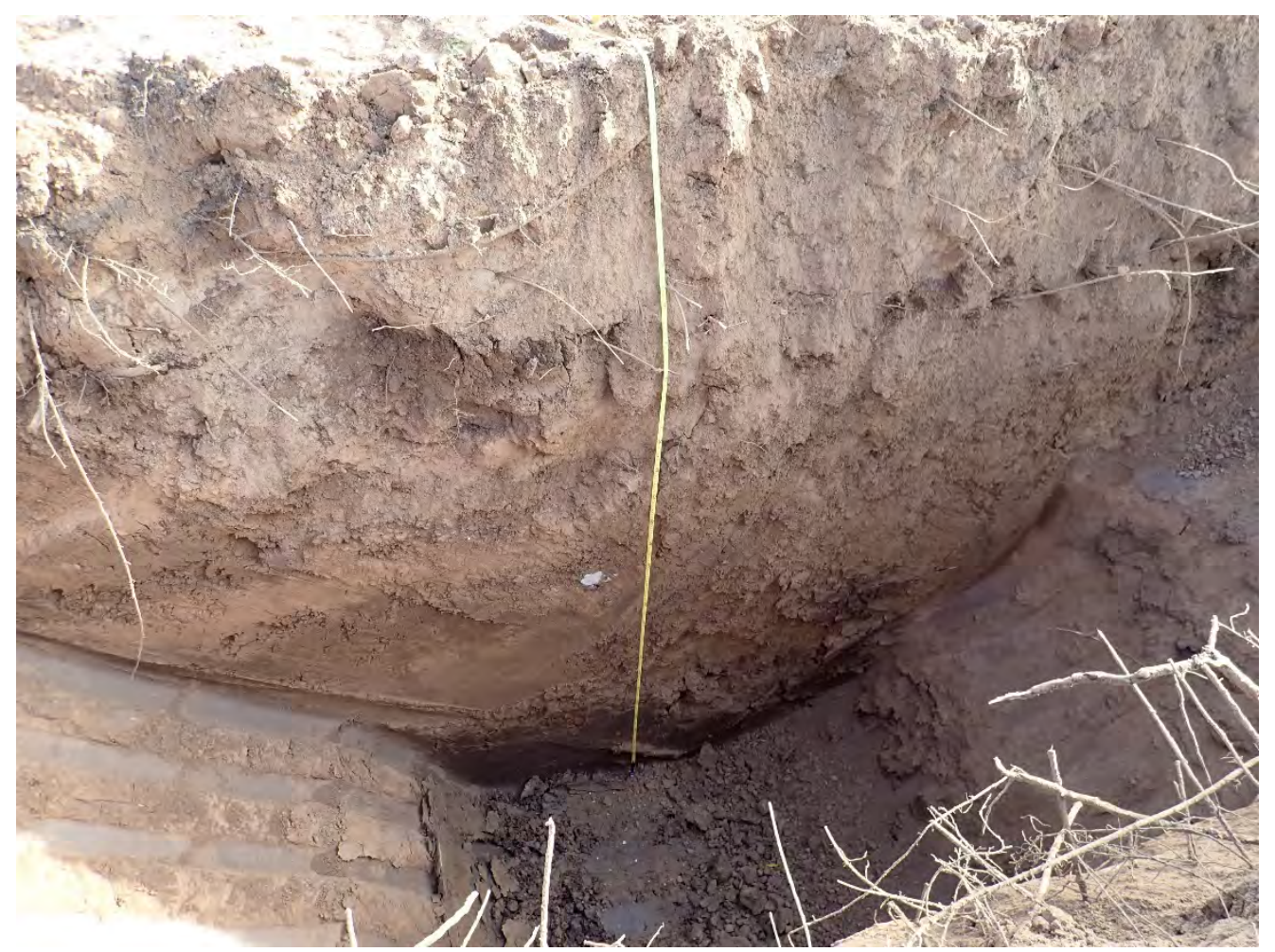

Figure B3. East wall profile of T1.2.

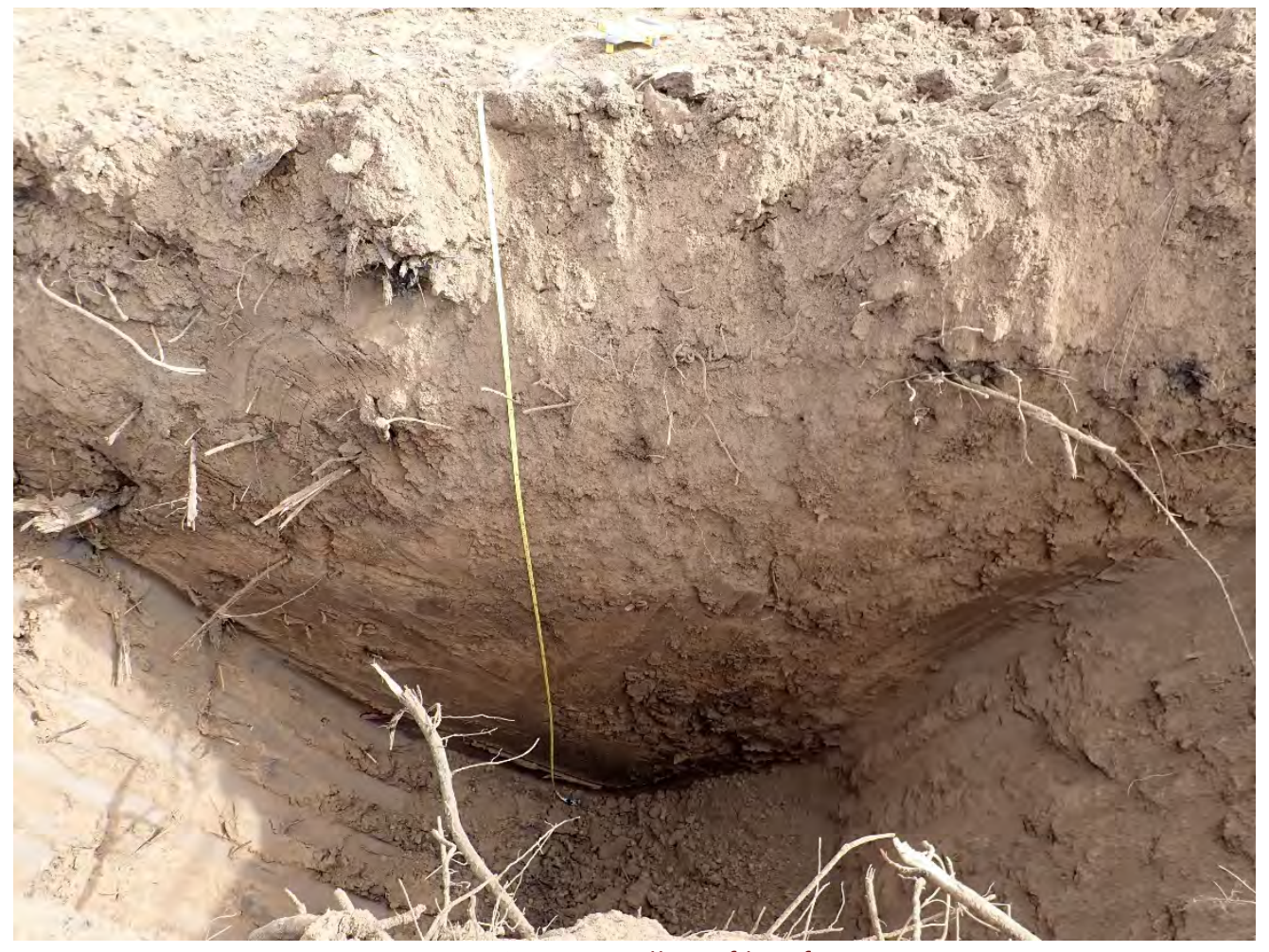

Figure B4. East wall profile of T1.3. 


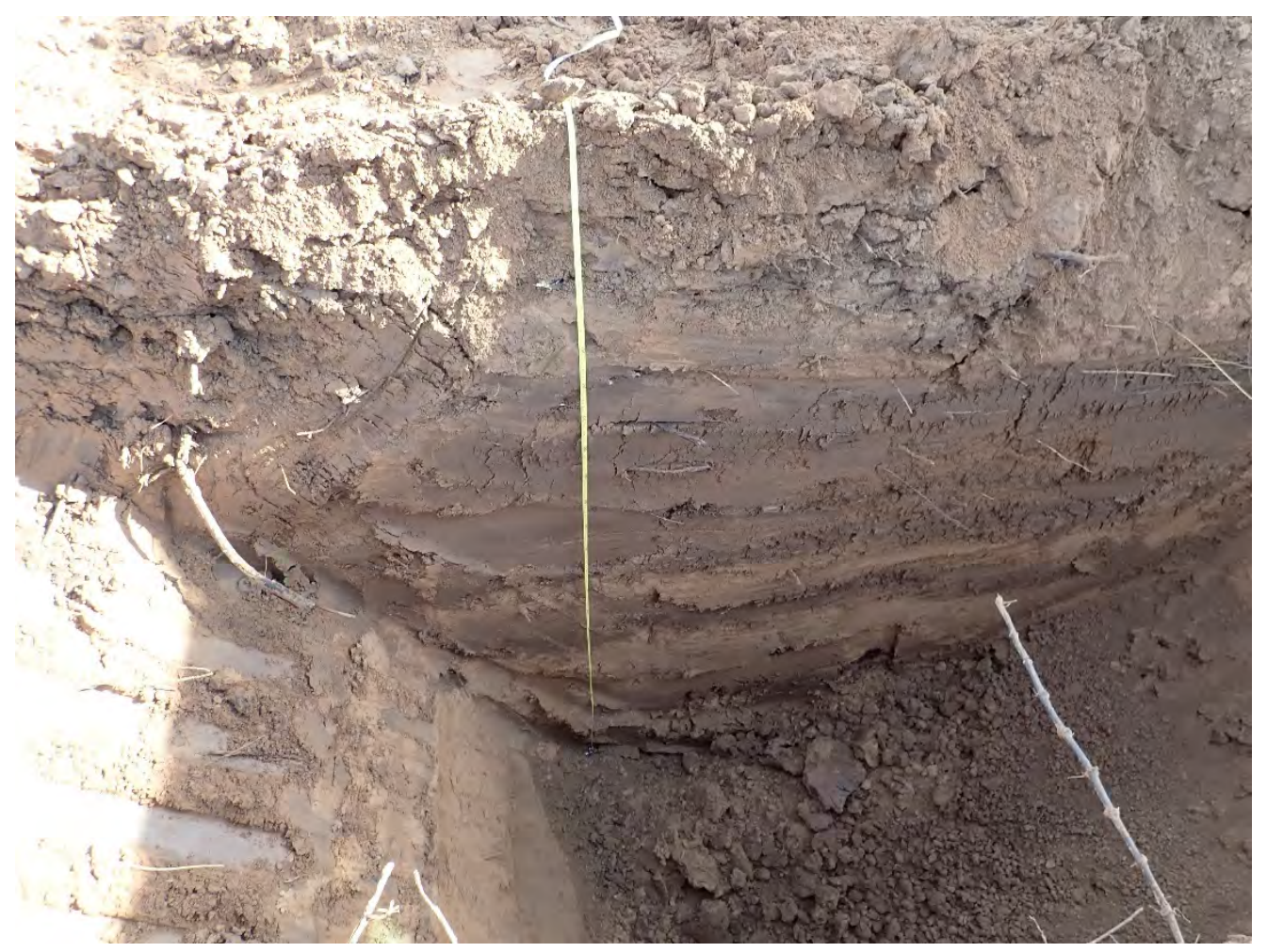

Figure B5. East wall profile of T1.4.

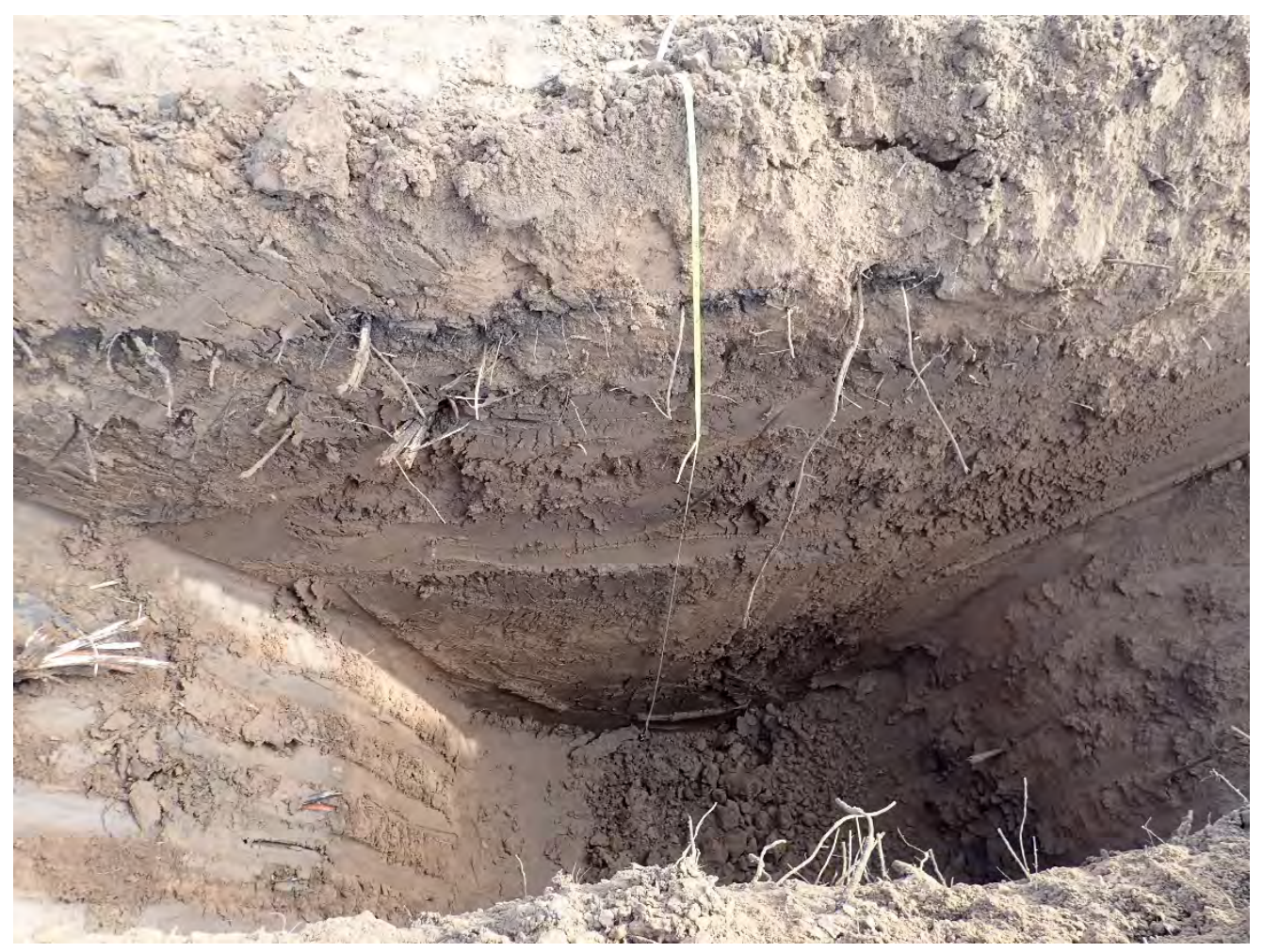

Figure B6. East wall profile of T1.5. 


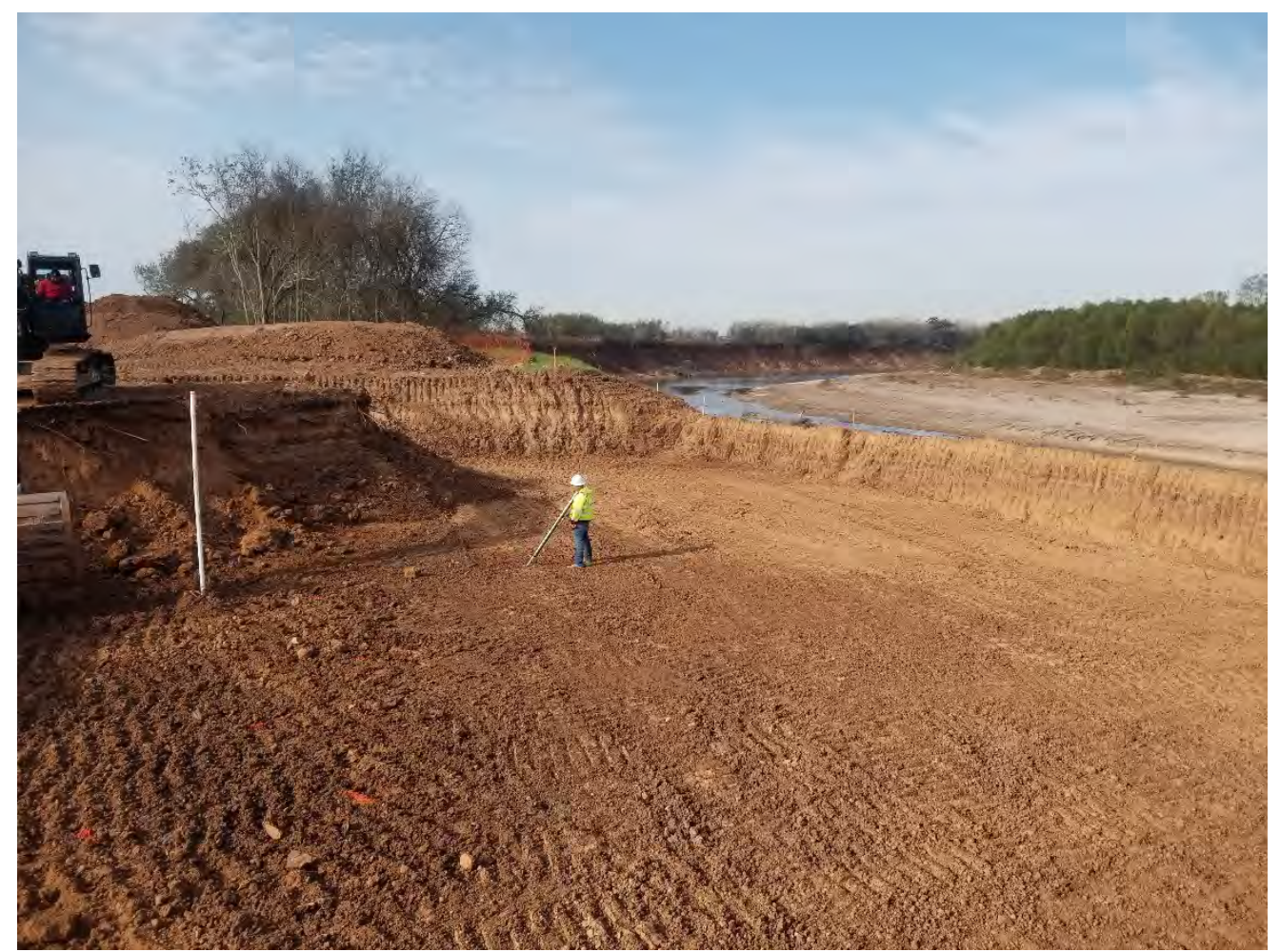

Figure B7. Overview of the excavated Structure 2 location. View is to the west.

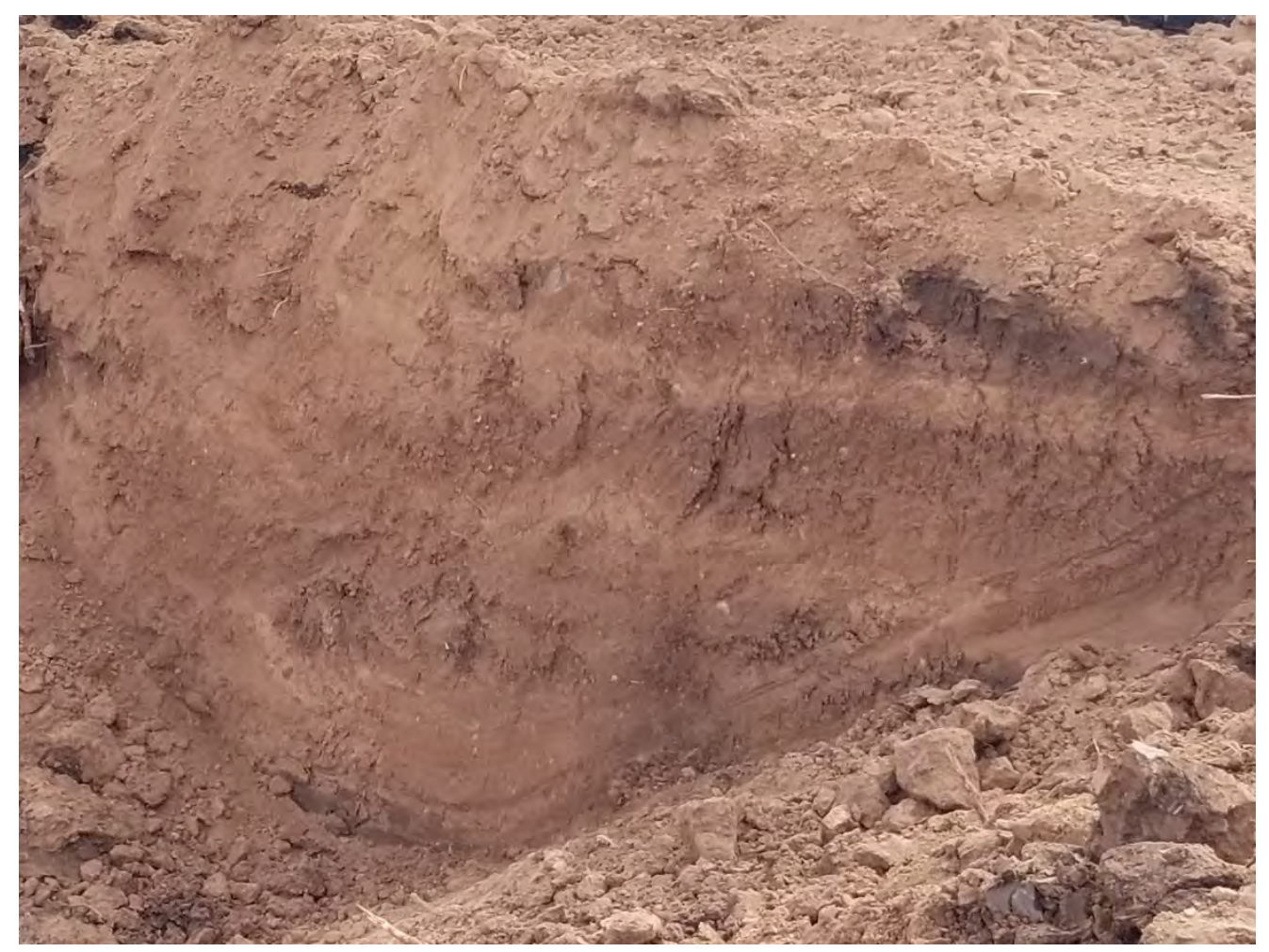

Figure B8. South wall profile of the excavated Structure 2 location. View is to the southeast. 


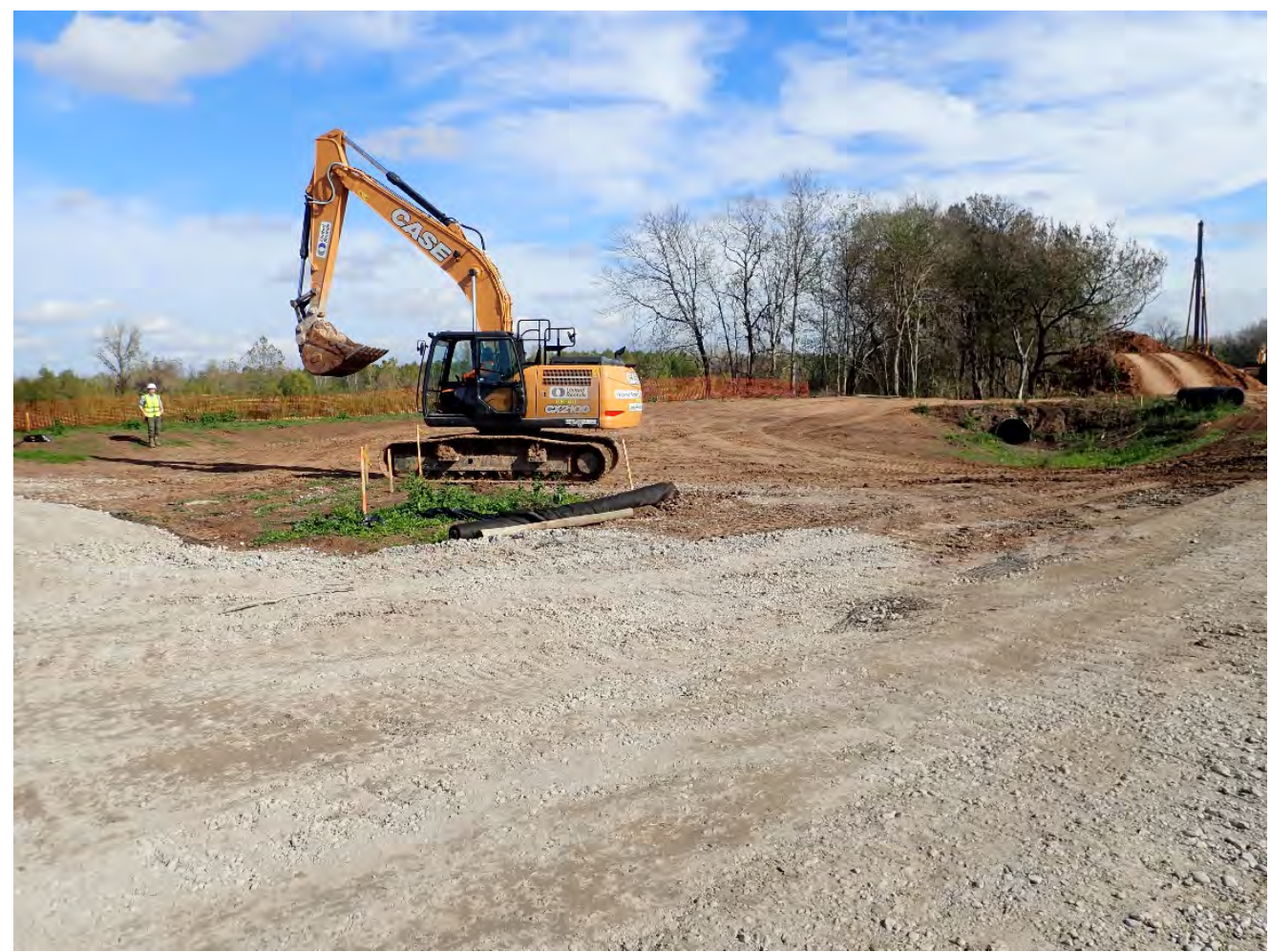

Figure B9. Overview of the Structure 3 location. View is to the northeast. Note gravel parking area and road along the workspace's west and south margins respectively, and culvert at the east margin.

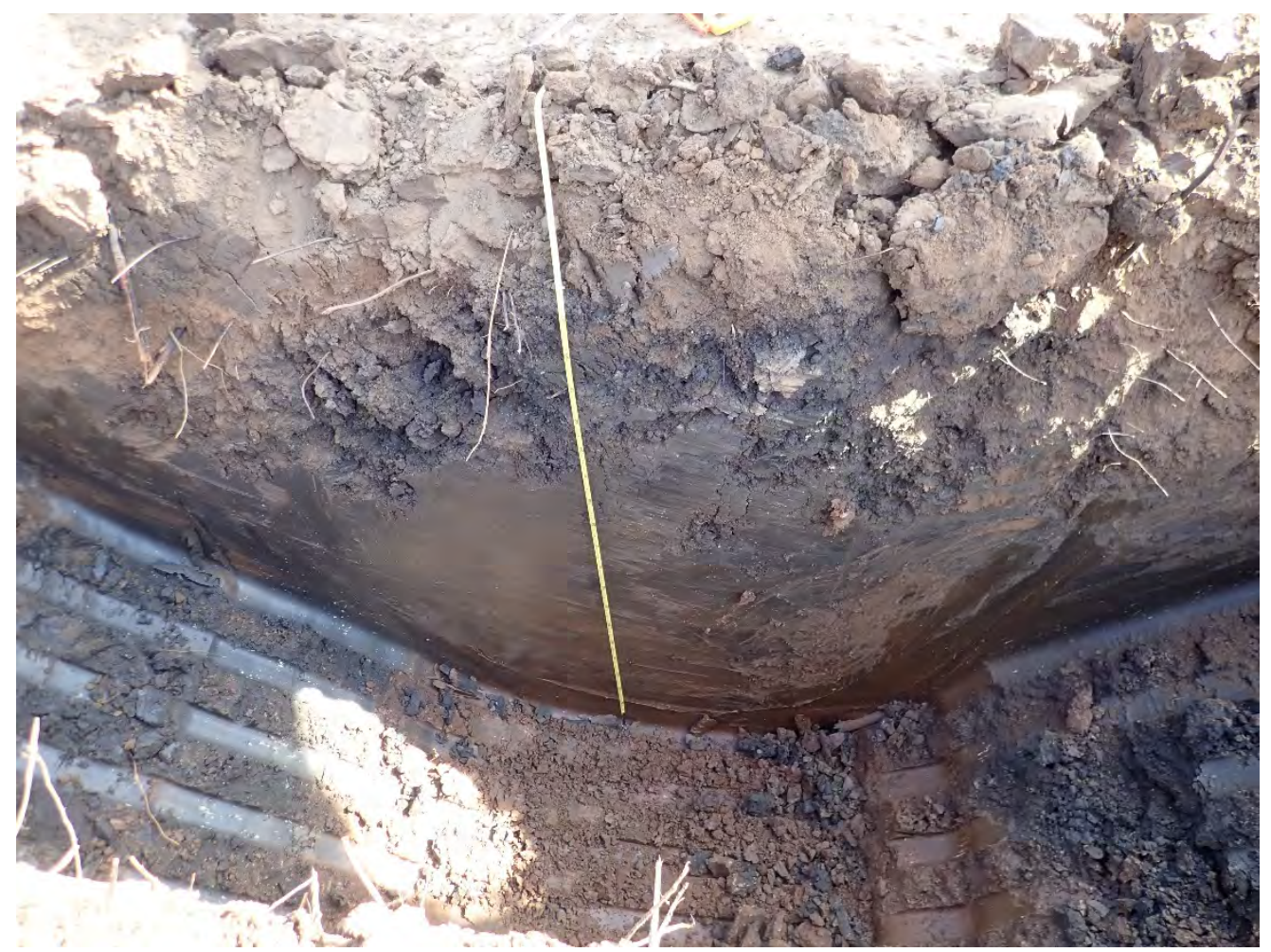

Figure B10. East wall profile of T3.1. 


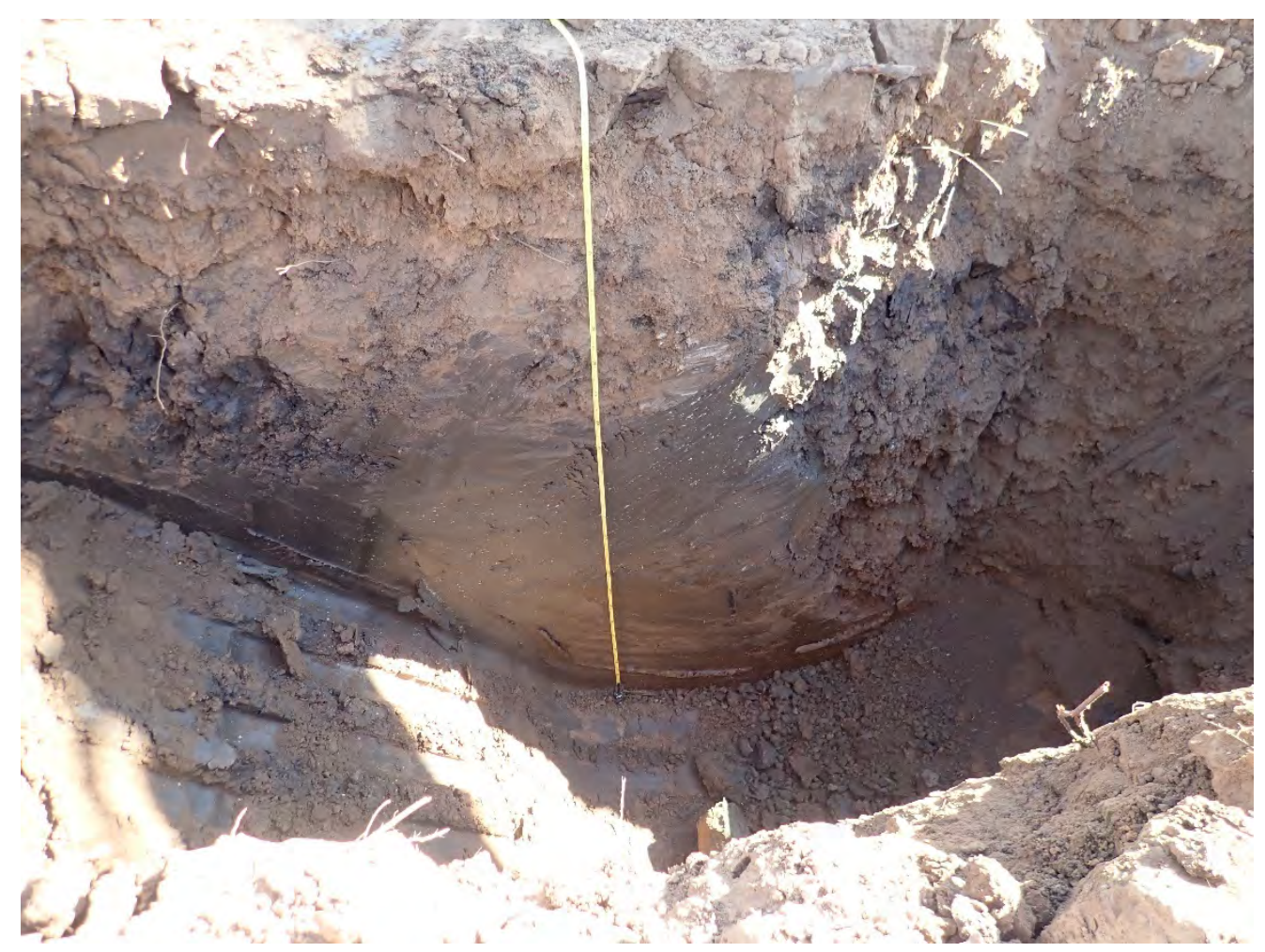

Figure B1 1. East wall profile of T3.2.

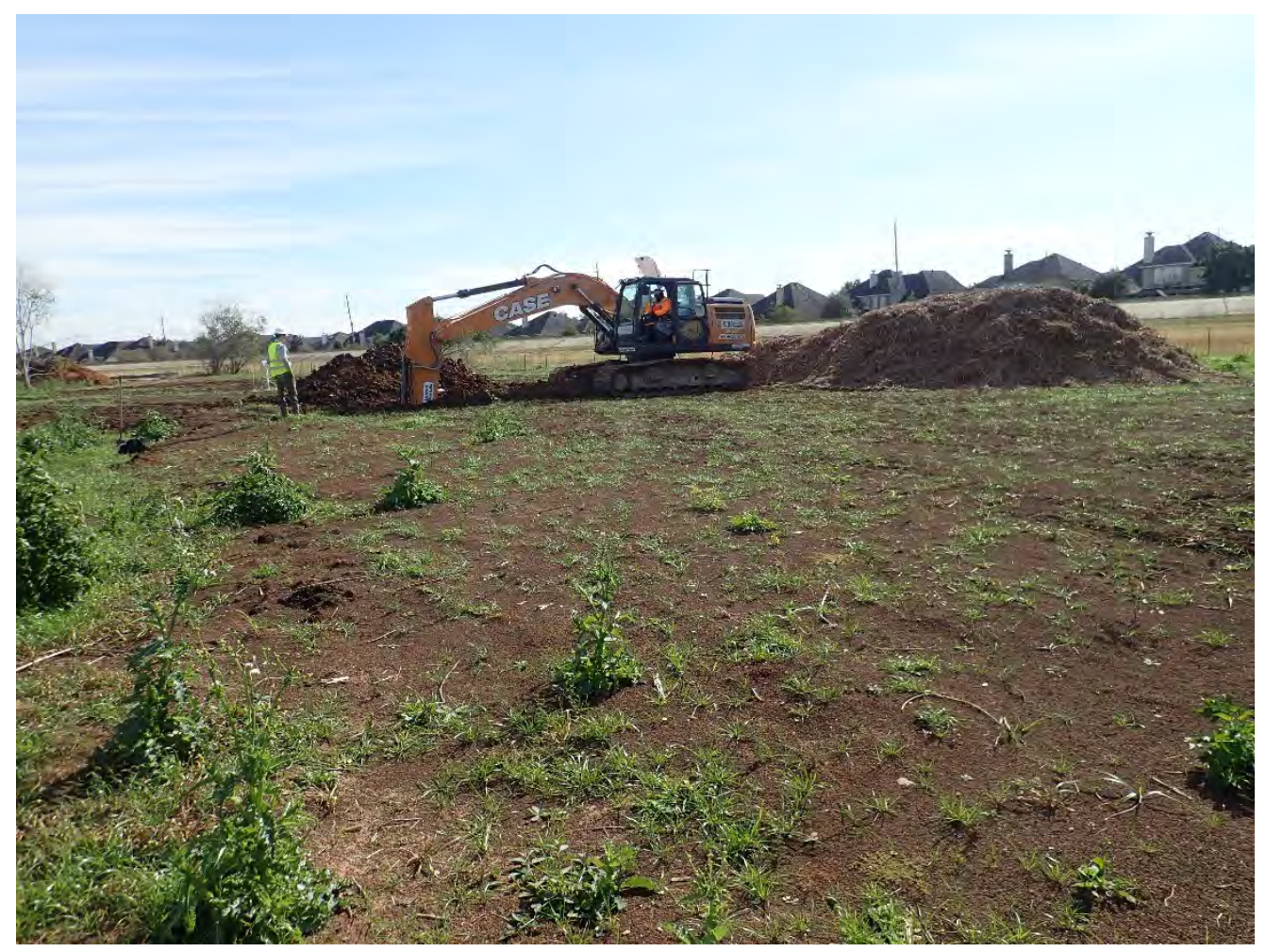

Figure B12. Overview of the Structure 4 location. Note brush pile within the center of the workspace. View is to the southeast. 


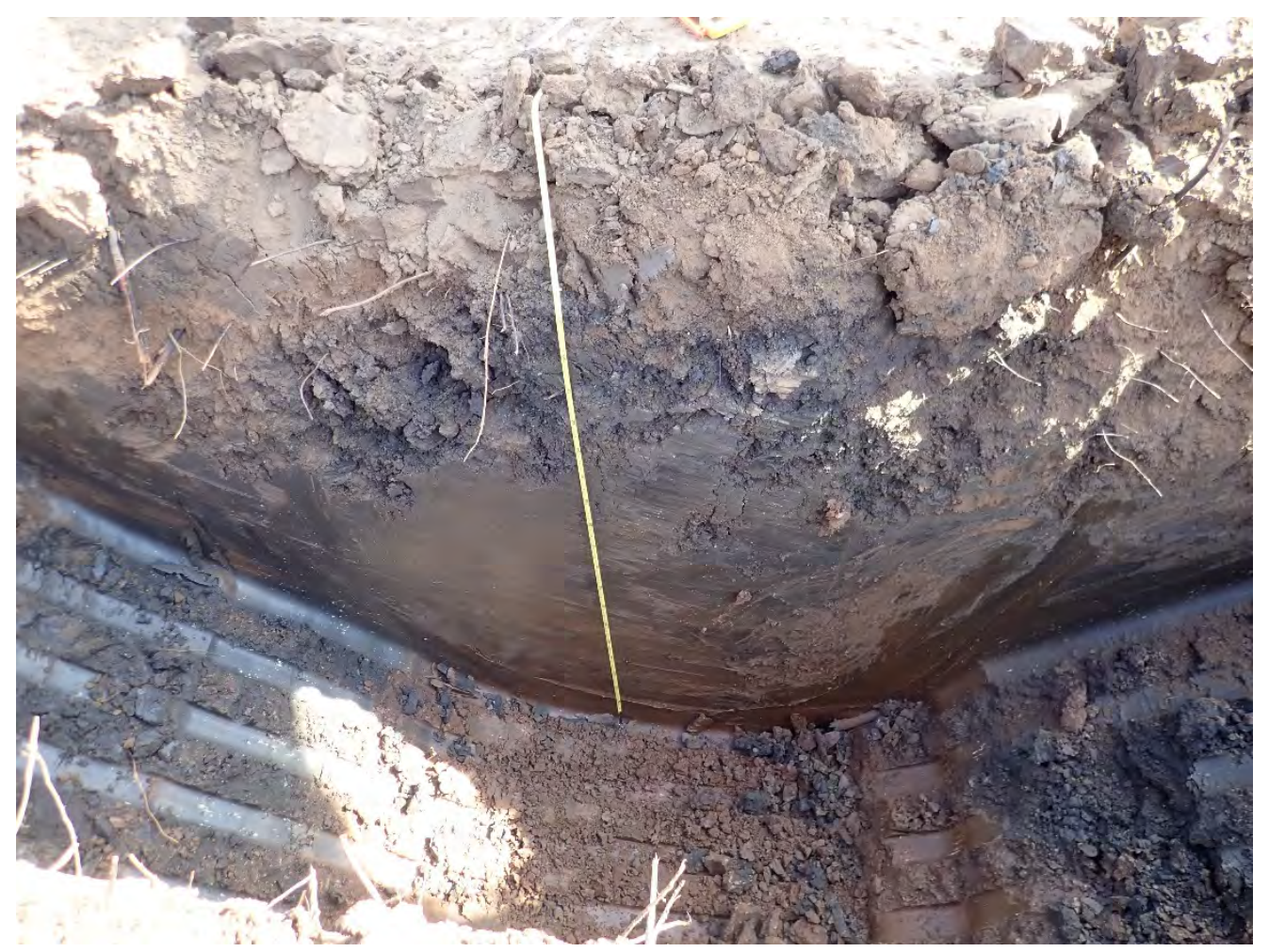

Figure B13. East wall profile of T4.1.

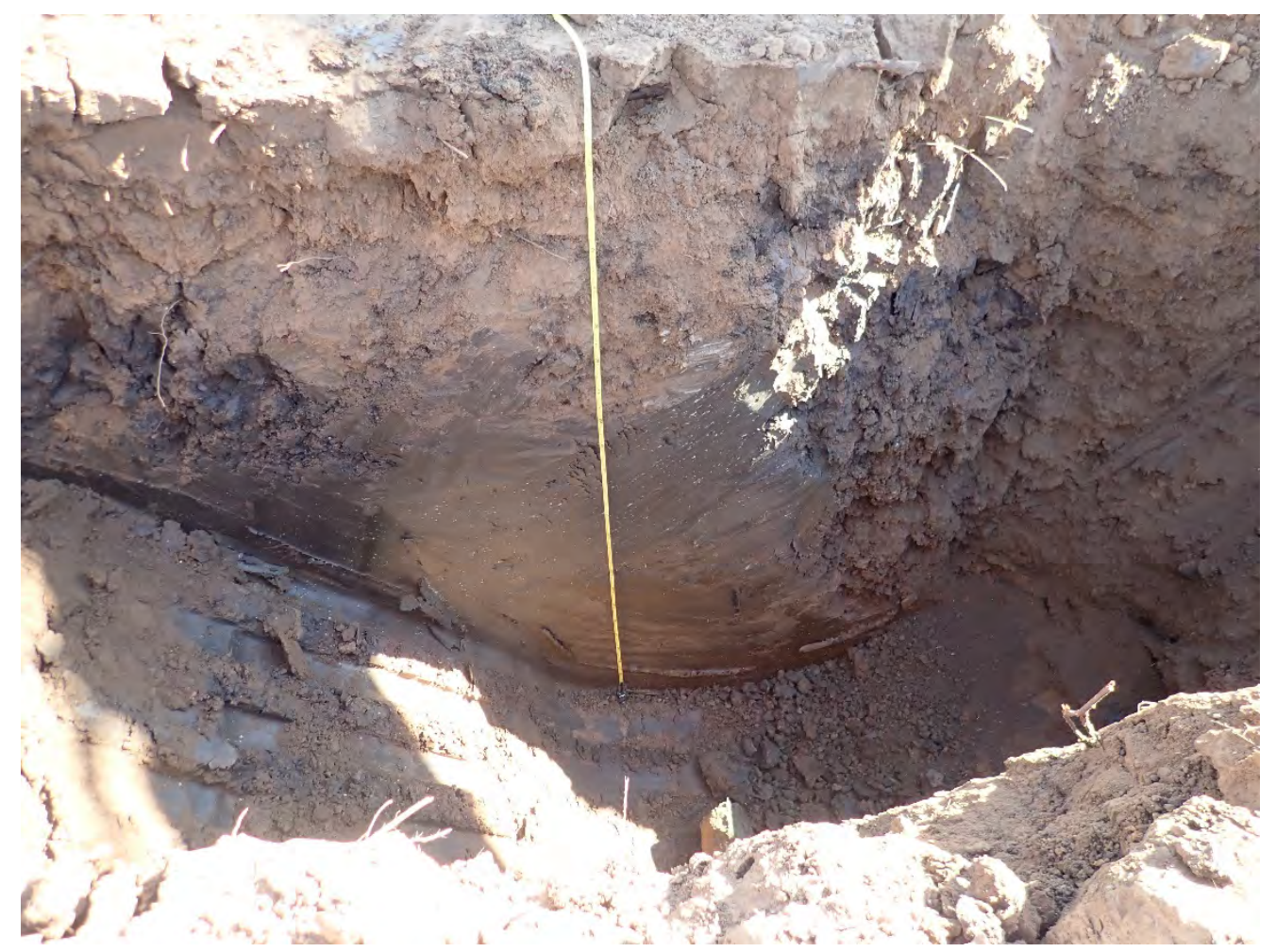

Figure B14. East wall profile of T4.2. 


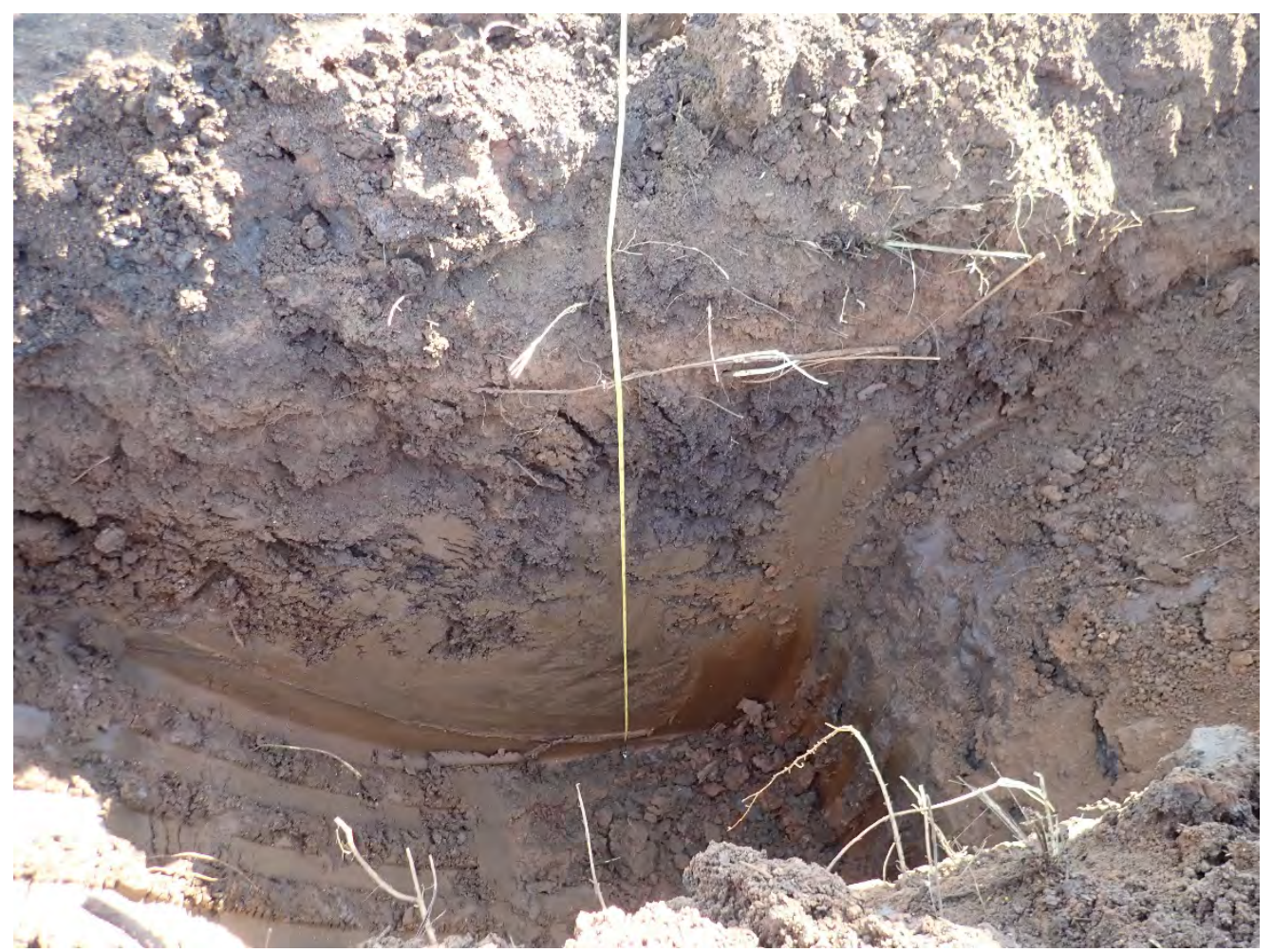

Figure B15. East wall profile of T4.4.

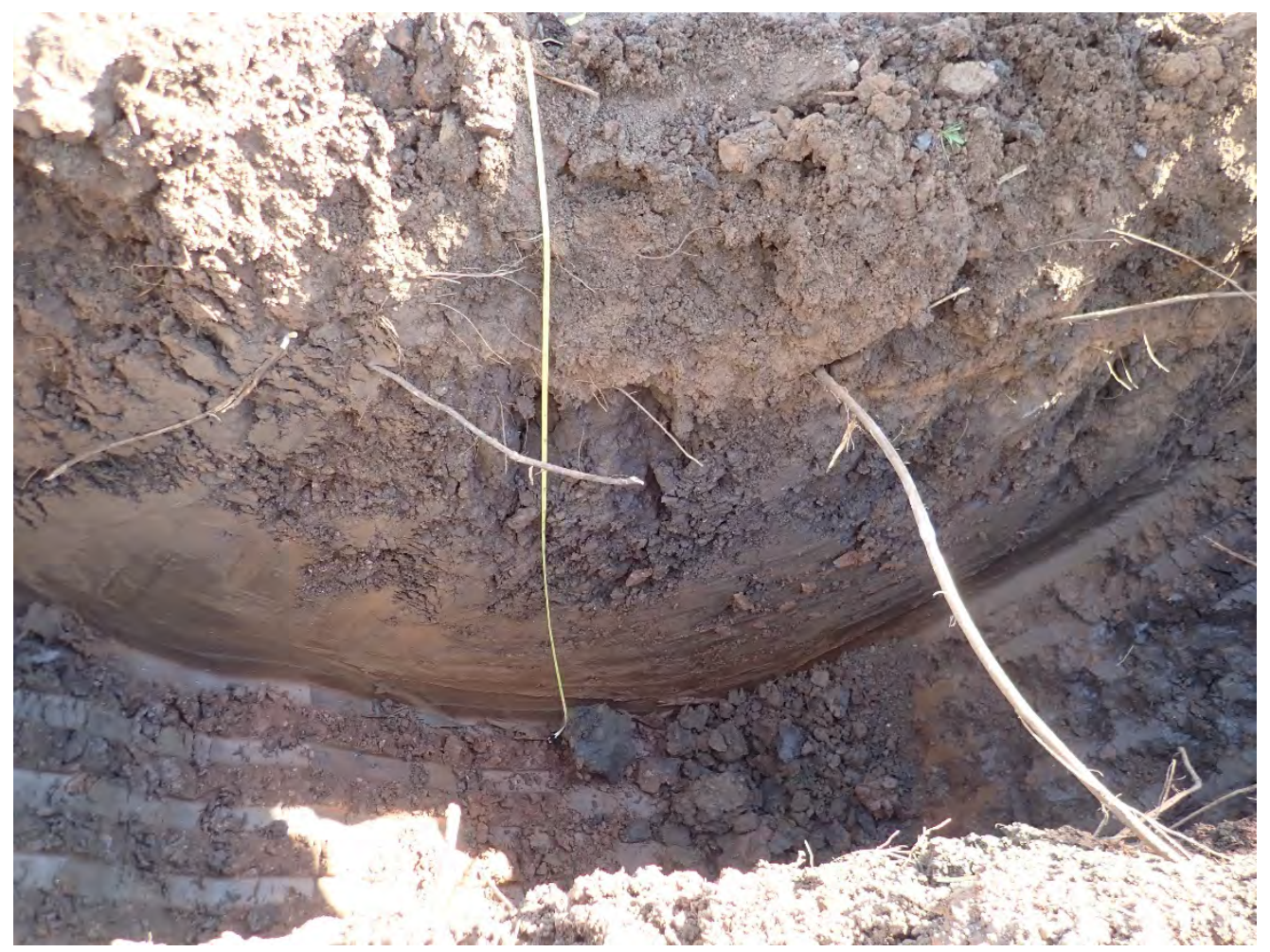

Figure B16. East wall profile of T4.5. 


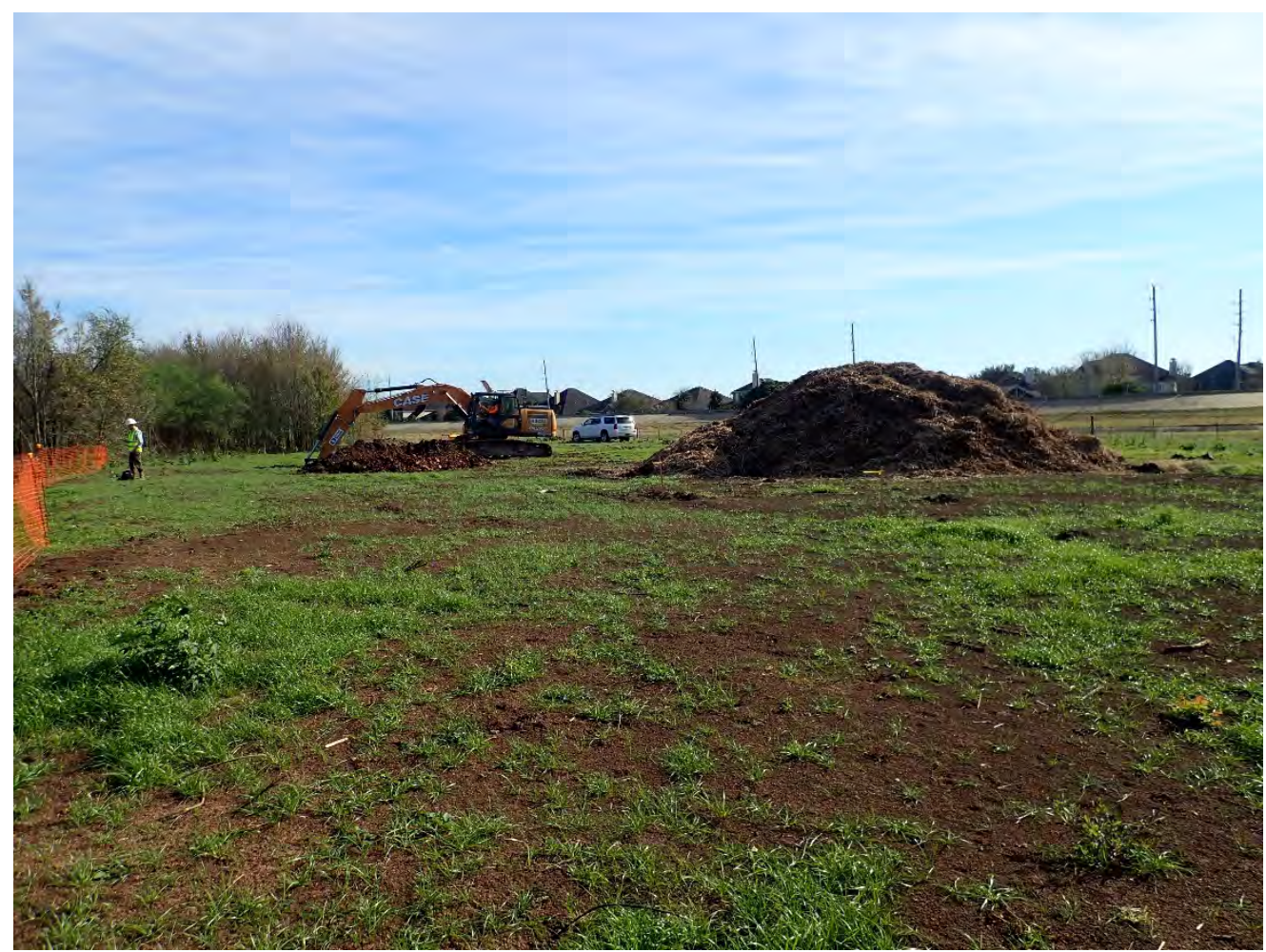

Figure B 17. Overview of the Structure 5 location. View is to the southeast. Note brush pile within the center of the workspace.

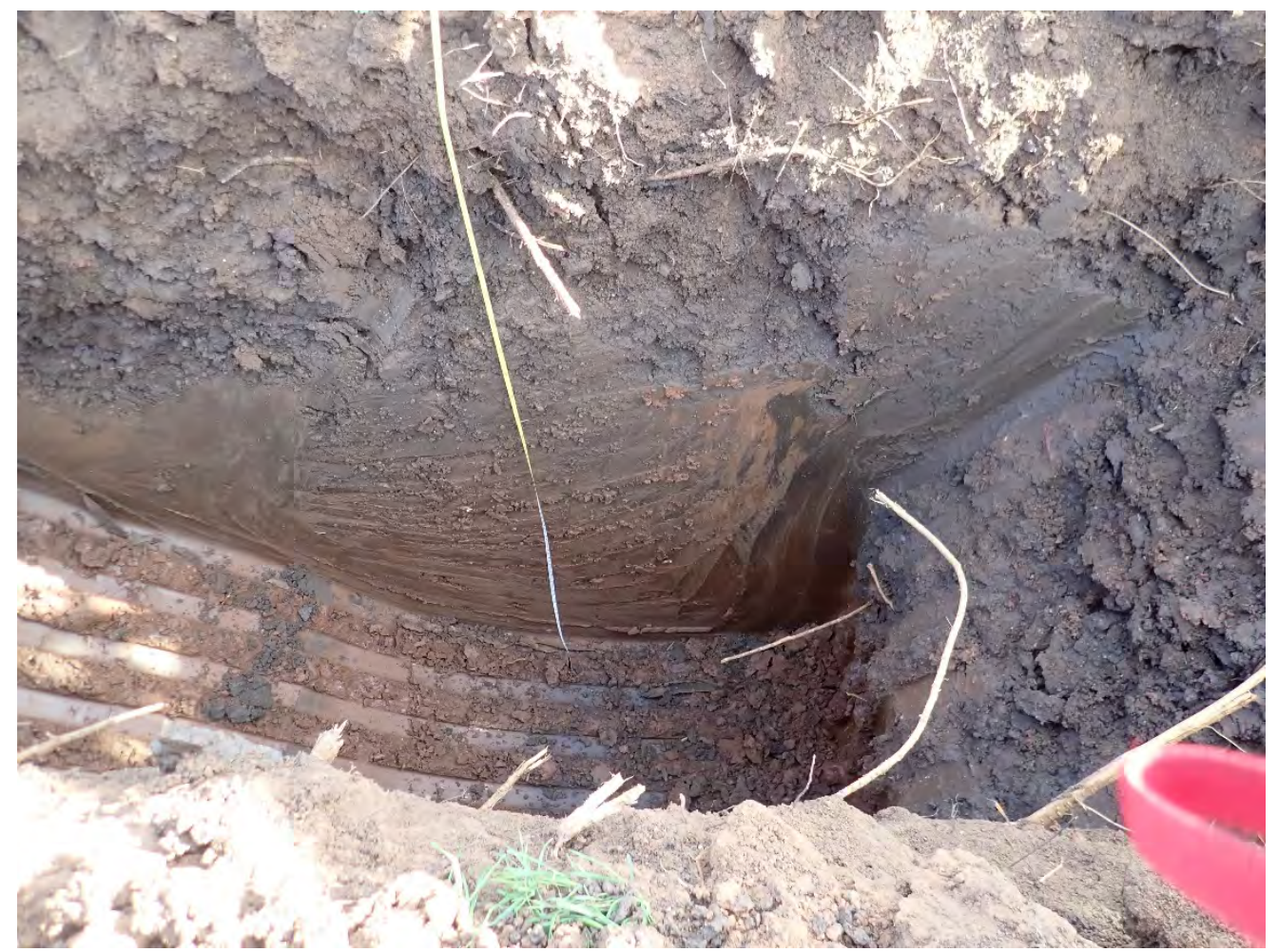

Figure B18. East wall profile of T5.1. 


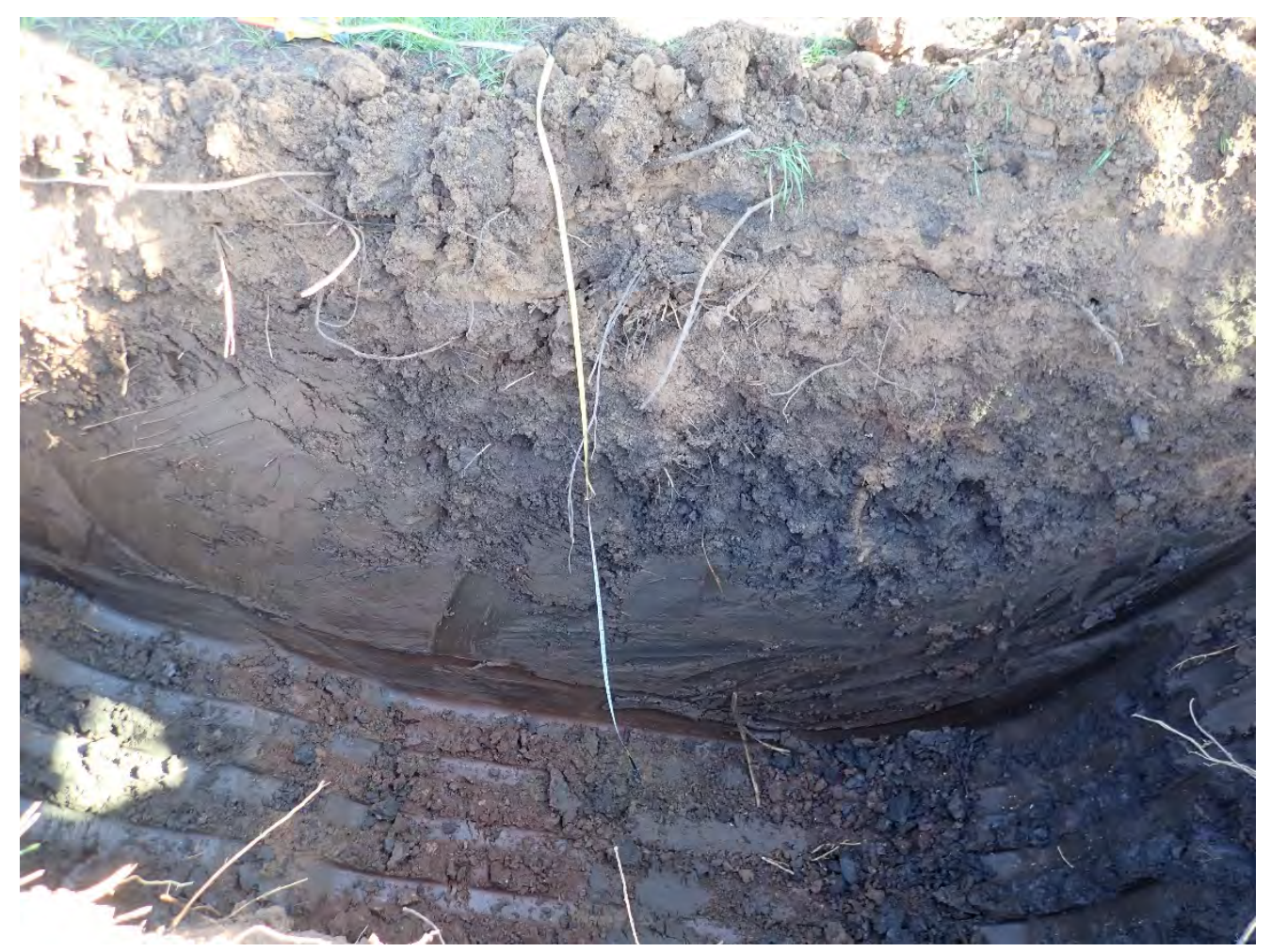

Figure B19. East wall profile of T5.2.

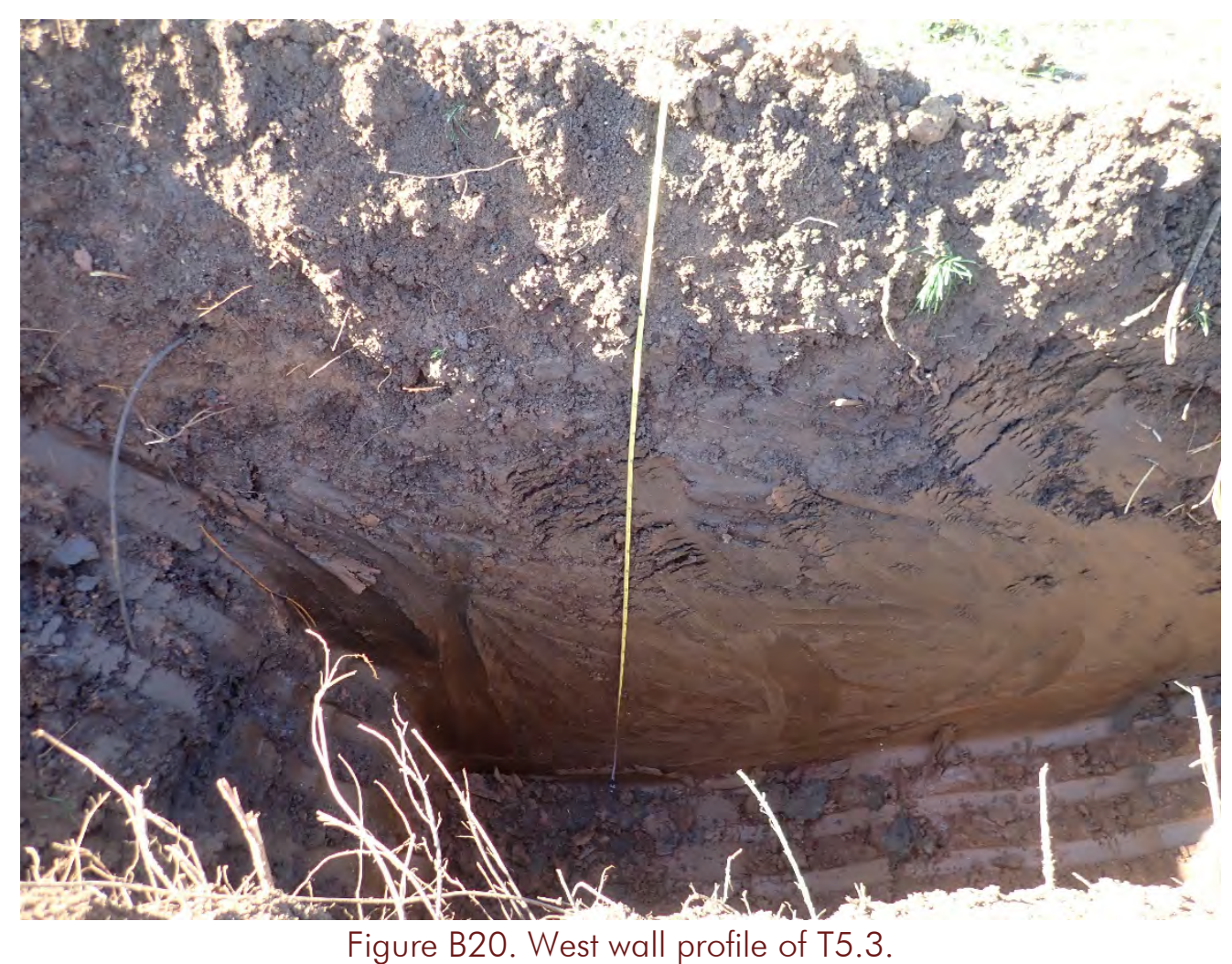




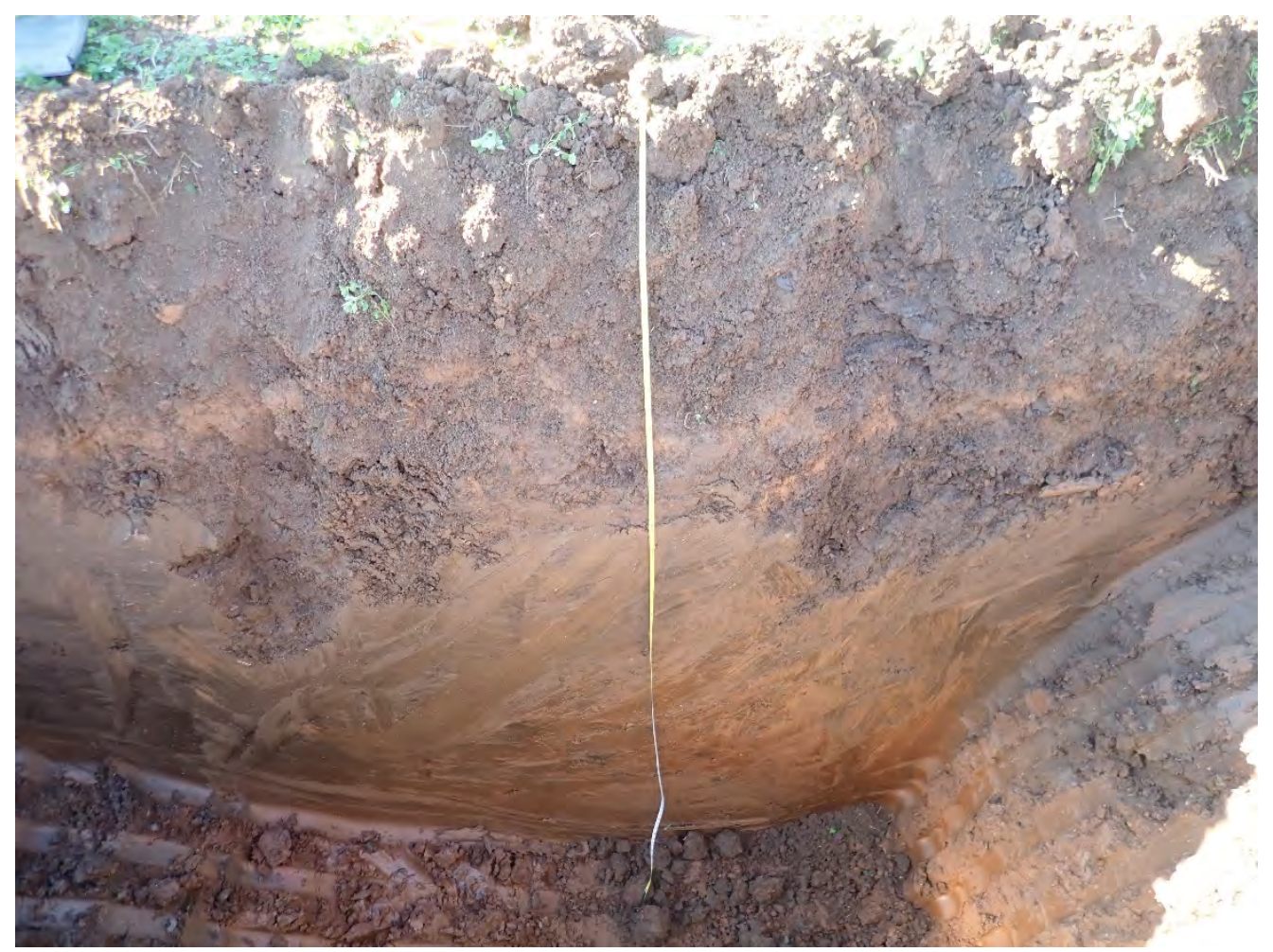

Figure B21. West wall profile of T5.4.

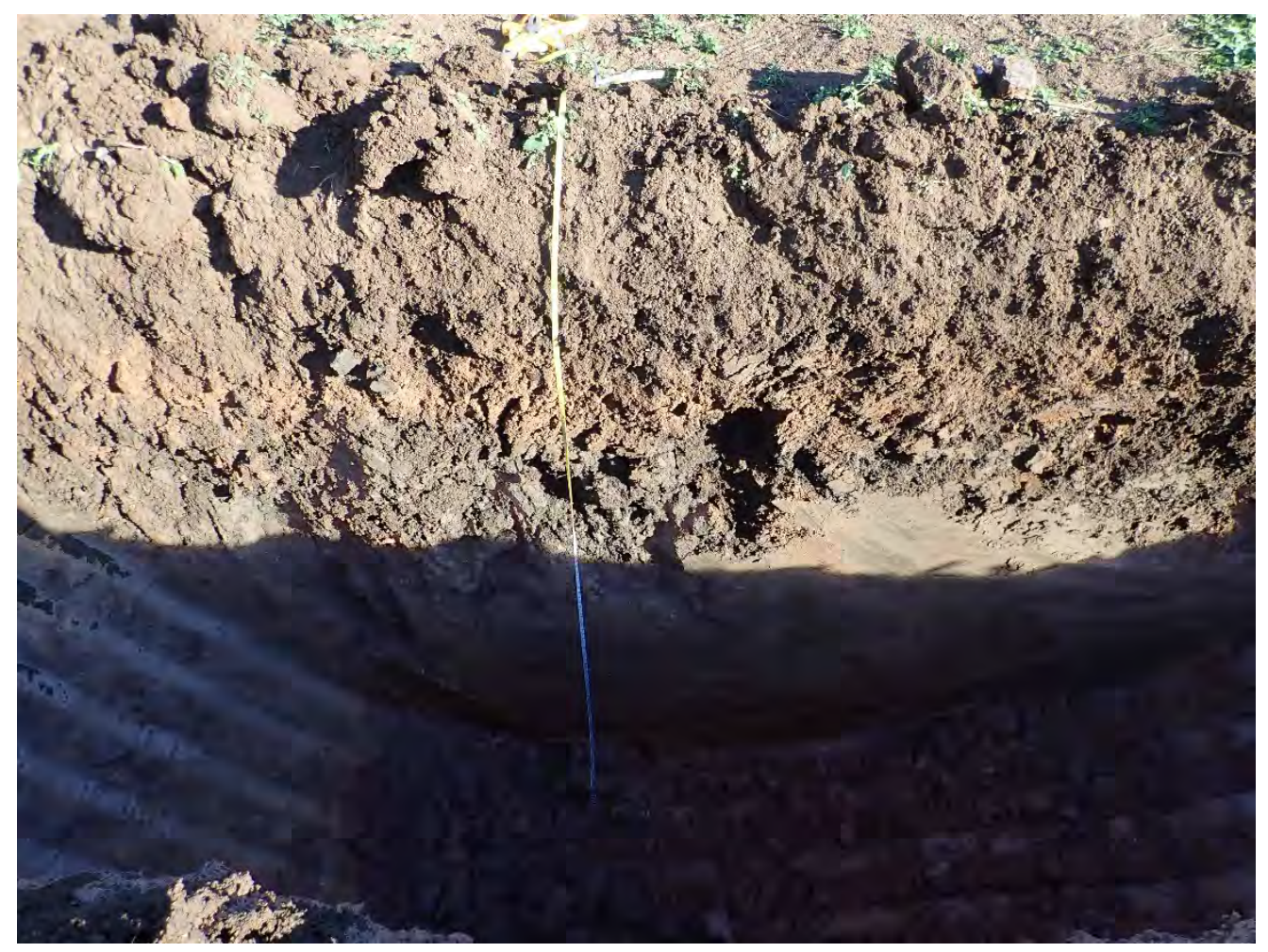

Figure B22. East wall profile of T5.5. 


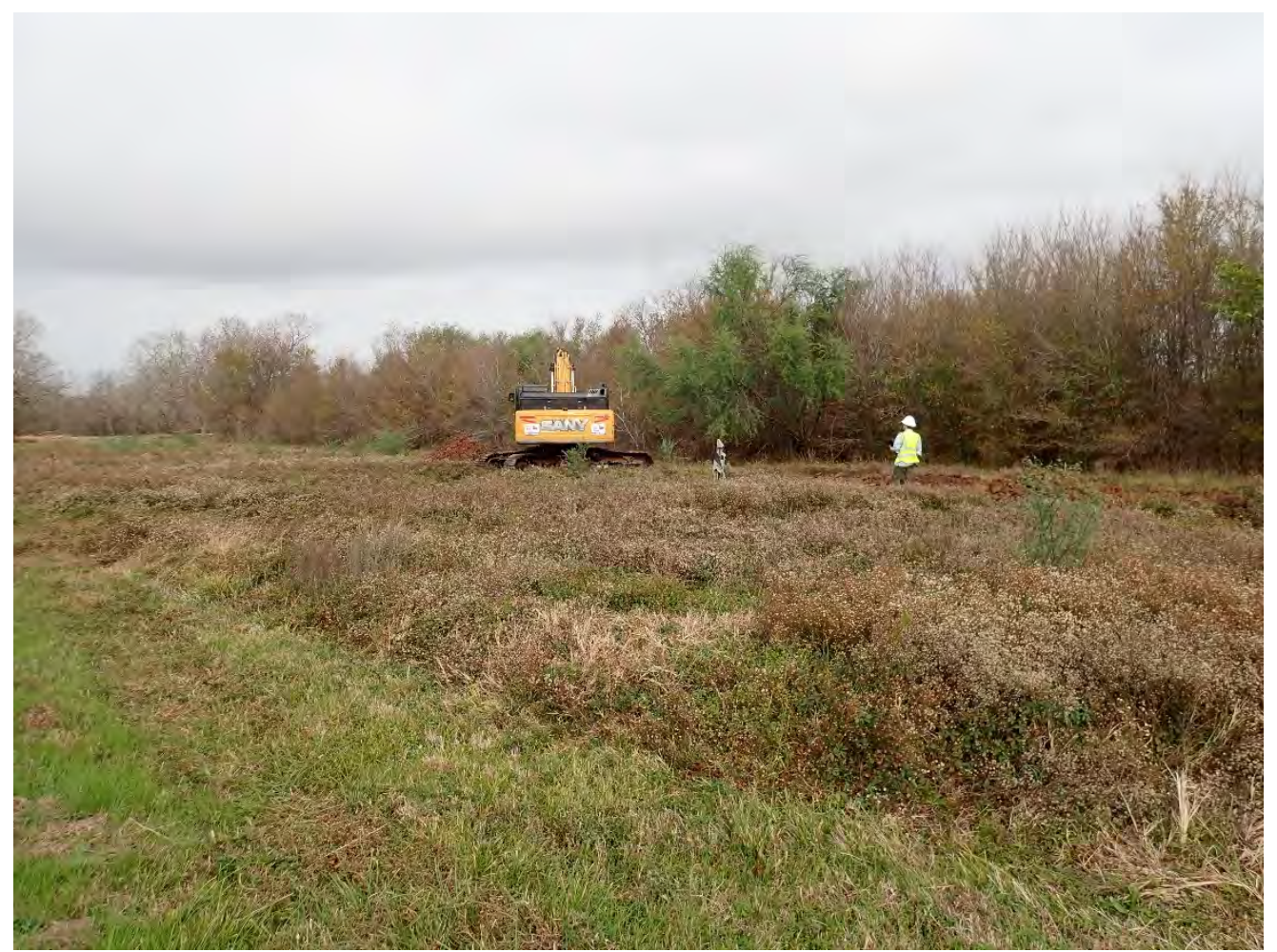

Figure B23. Overview of the Structure 6 location. View is to the northwest.

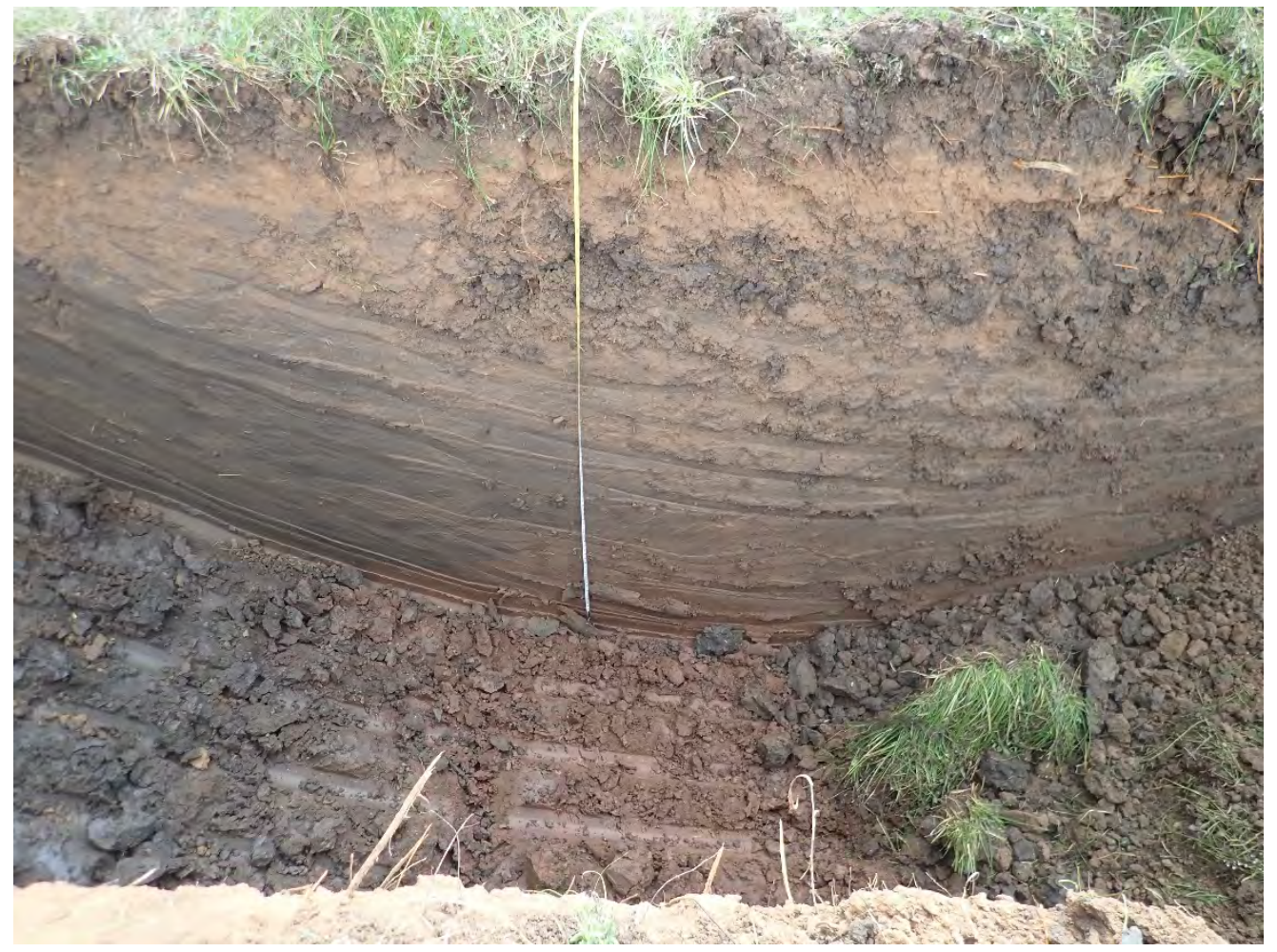

Figure B24. East wall profile of T6.1. 


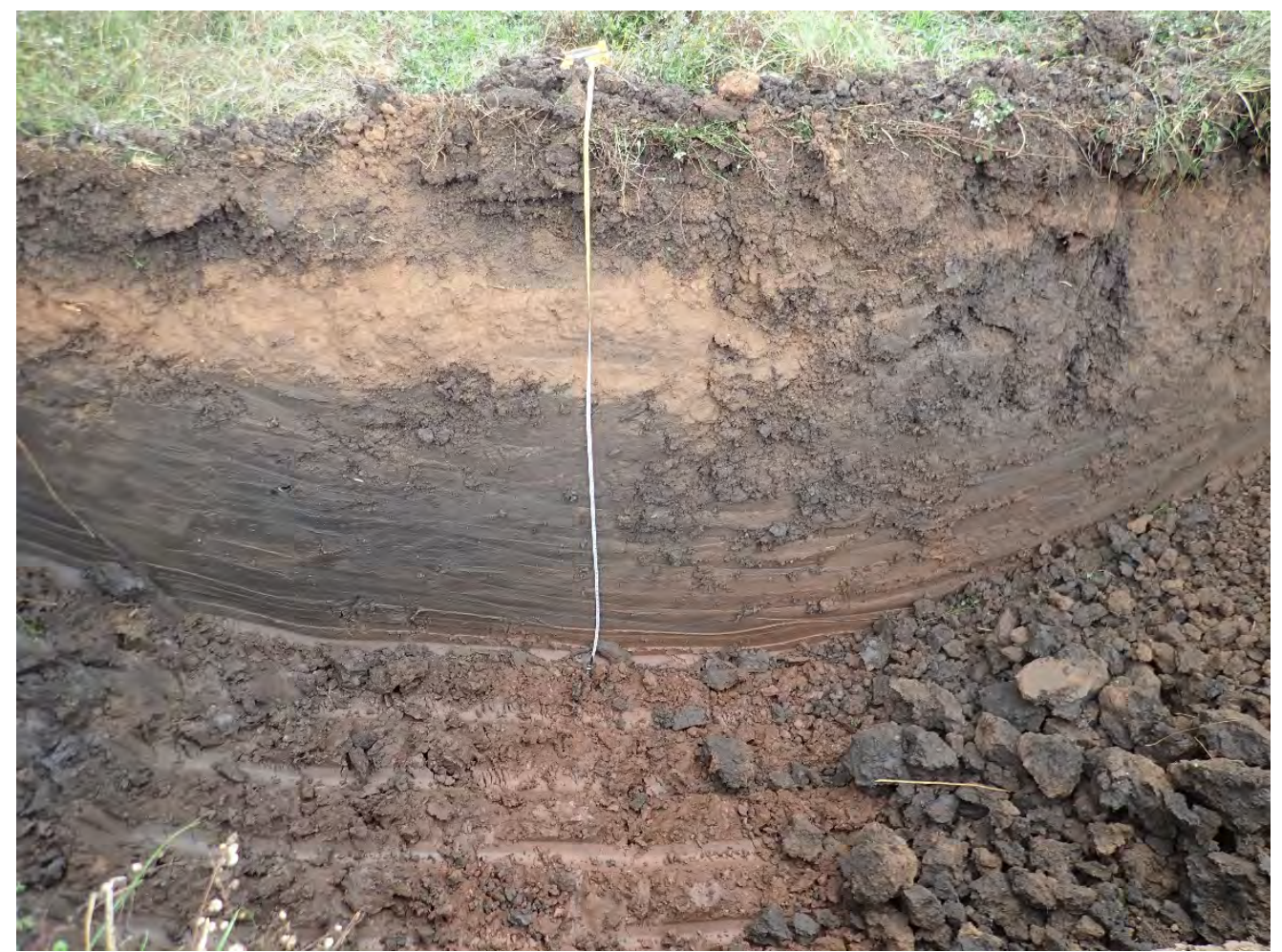

Figure B25. East wall profile of T6.2.

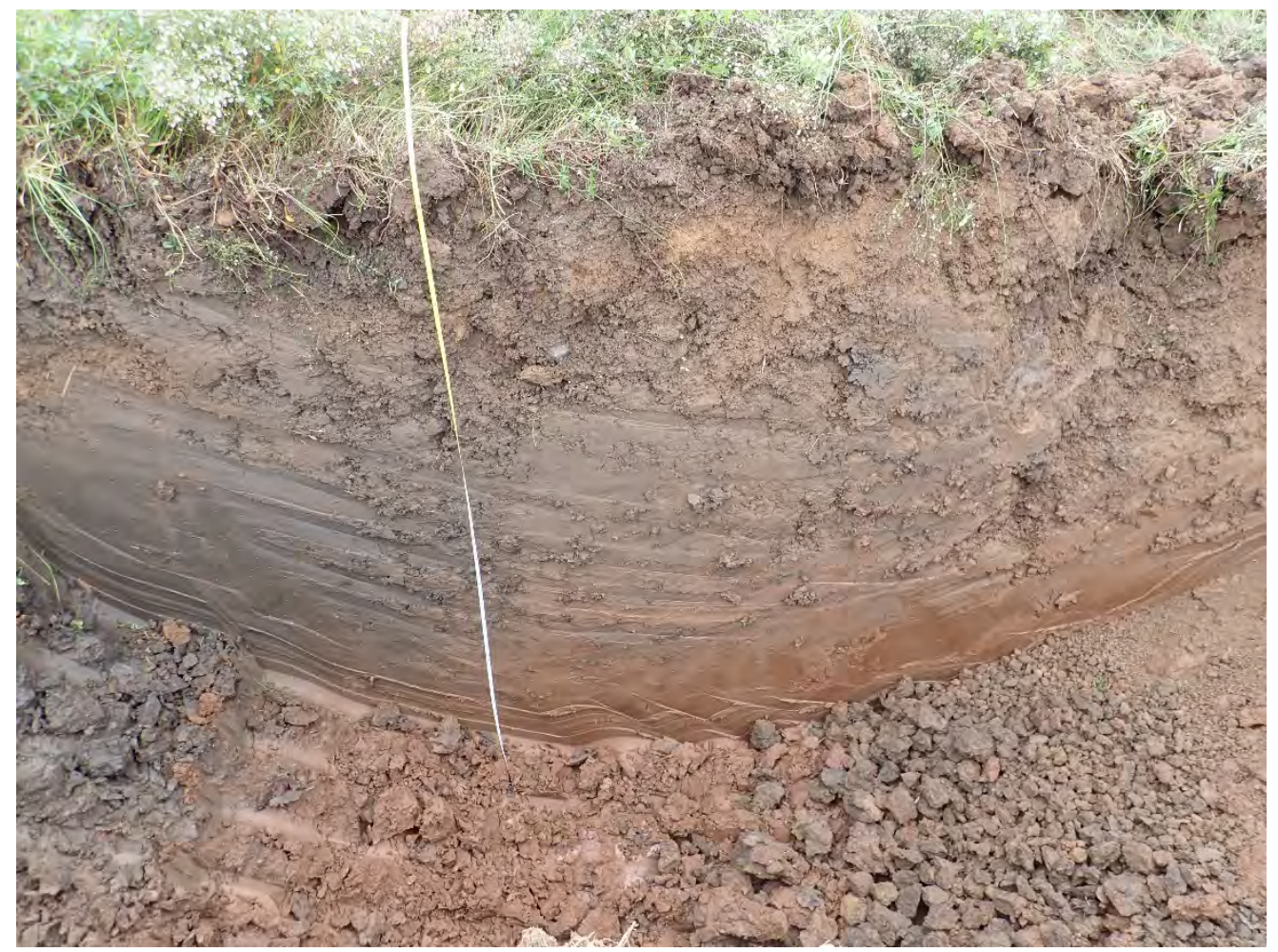

Figure B26. East wall profile of T6.3. 


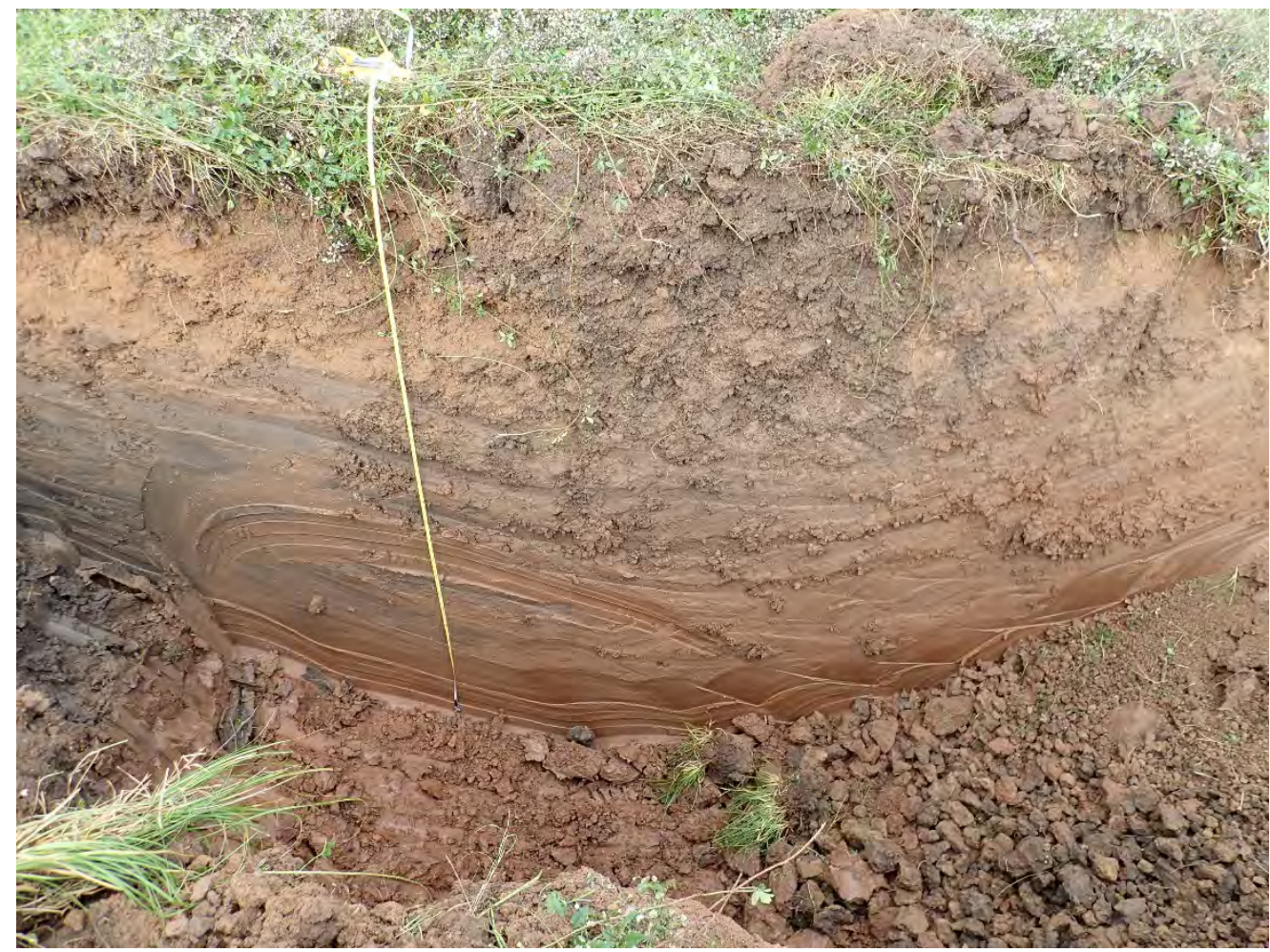

Figure B27. West wall profile of T6.4.

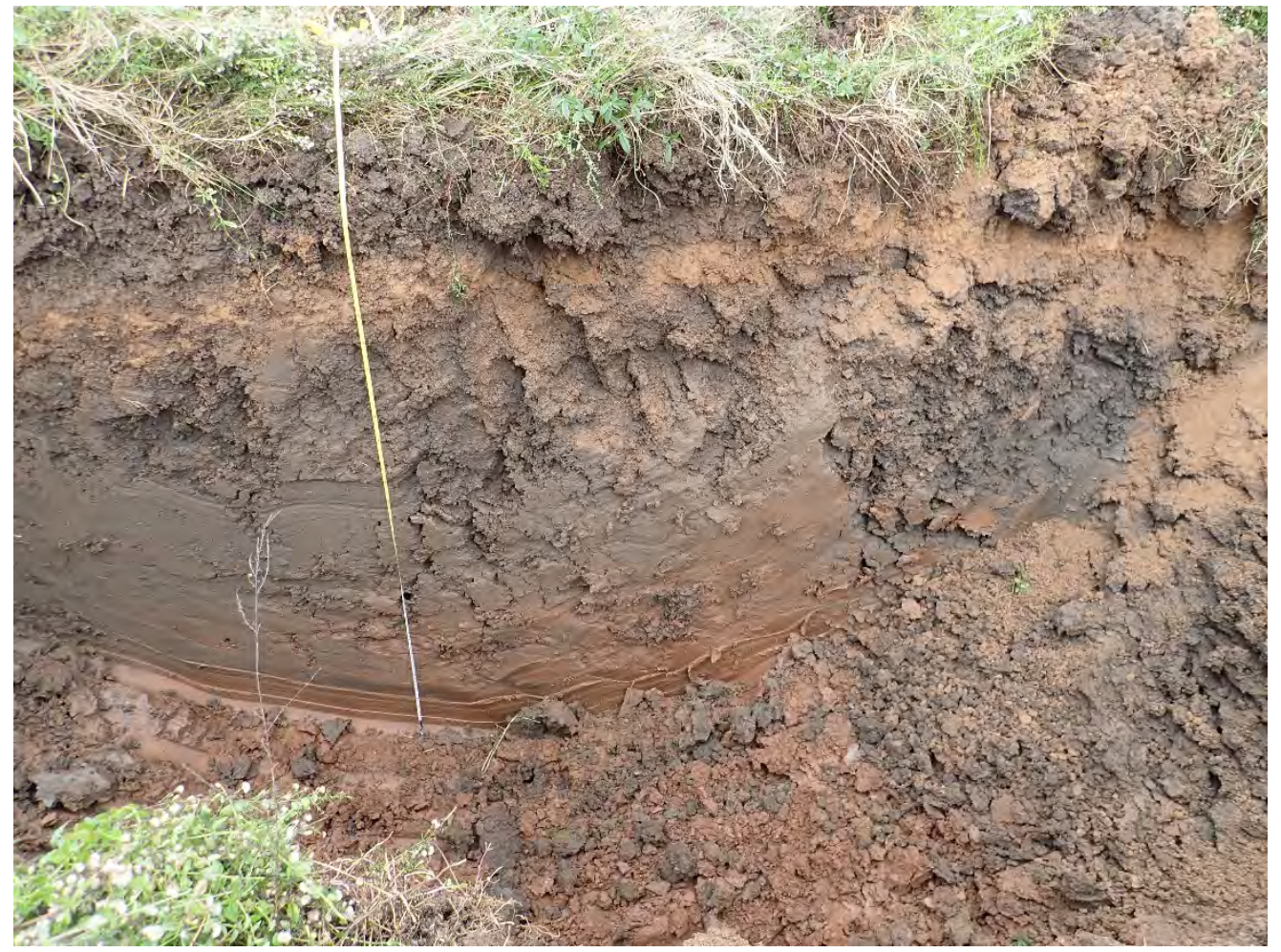

Figure B28. West wall profile of T6.5. 
